\title{
The rise and fall of approximants in the Tuparian languages*
}

\begin{abstract}
This paper addresses the evolution of the approximant series in the languages of the Tuparian branch of the Tupian family, native to the region comprised between the middle course of the Guaporé/Iténez and the headwaters of the Machado/Ji-Paraná (southern Rondônia, Brazil). It is shown that in addition to the approximant series of Proto-Tuparian (which, we argue, comprised ${ }^{*} \beta,{ }^{*} j,{ }^{*} w$ ), some daughter languages created innovative approximants from a variety of sources, such as non-low vowels $\left({ }^{*} o /{ }^{*} i\right)$, post-oralized nasals $\left({ }^{*} m b /{ }^{*} n d /{ }^{*} \eta g\right.$, by the way of ${ }^{*} b /{ }^{*} d /^{*} g$ ), and hiatus-filling glides. The evolution of these sounds is discussed in great detail; in particular, we argue that at least some approximants have been historically fortitioned in all Tuparian languages. A special attention is given to the subgrouping of the Tuparian branch.
\end{abstract}

Keywords: Tuparian languages; Tupian languages; approximants; fortition; comparative method.

\section{Introduction}

This paper examines the phonological development of the approximant series throughout the reconstructed history of the Tuparian languages (Tupian family), a group of indigenous languages spoken in what is now the Brazilian state of Rondônia. We will argue that ProtoTuparian inherited a series of approximants $\left({ }^{*} \beta,{ }^{*} j,{ }^{*} w\right)$ from its ancestor, Proto-Tupian, which were later subject to massive fortition processes in the history of all contemporary Tuparian languages. In addition, we hypothesize that some Tuparian languages innovated at some point by creating approximants from two types of Proto-Tuparian sources: non-low vowels $\left({ }^{*} 0,{ }^{*} i\right)$ and postoralized nasals $\left({ }^{*} m b,{ }^{*} n d\right.$, and $\left.{ }^{*} \eta g\right)$.

The Tupian language family is one of the most diversified and geographically disperse genetic units of South America. Its approximately 50 languages are spoken throughout a vast area which spans from the northern Amazon to the extreme south of Brazil and are classified into ten universally recognized low-level branches: Arikém, Tuparí, Mondé, Ramarama, Puruborá, Mundurukú, Juruna, Sateré-Mawé, Awetí, and Tupí-Guaraní (Rodrigues \& Cabral 2012). Recent studies have shown that Ramarama and Puruborá likely constitute a valid clade (Galucio \& Gabas Jr. 2002), as do Sateré-Mawé, Awetí, and Tupí-Guaraní (Awetí and TupíGuaraní are more closely related to each other than any of them to Sateré-Mawé; Corrêa-daSilva 2010, Meira \& Drude 2015). From a geographic point of view, the genetic diversity within the family reaches its peak in what is now the Brazilian state of Rondônia, which has therefore been identified as the likely Urheimat of Proto-Tupian (Rodrigues 1958: 683).

The Tuparian branch - also known in earlier literature as Kanoé (Rodrigues 1958: 682), Mekens (Hanke et al. 1958: 188), or Makuráp/Macuráp (Loukotka 1963: 45, 1968: 122) after different members of the branch (both Kanoé and Mekens refer to the language now known as

* We thank an anonymous JoLR reviewer for comments which helped improve the manuscript. Nikulin is grateful to Ana Vilacy Galucio for discussions on the synchronic and historical phonology of the Tuparian languages. Andrade is further grateful to Luciana Storto and Denny Moore for providing original recordings of Makurap. The usual disclaimers apply.

Journal of Language Relationship • Вопросы языкового родства • 18/4 (2020) • Pp. 284-319 • ( The authors, 2020 
Mekéns or Sakurabiat) - includes the following languages. Wayoró (Glottocode [wayo128], ISO 639-3 [wyr]) is spoken in the Terra Indígena Rio Guaporé by three elderly speakers at the time of writing (Nogueira 2019: 3). Nogueira (2019: 4) also reports lexical and phonological differences between the varieties traditionally spoken by the Kupndiiriat and Ngwayoroiat groups. Tuparí (Glottocode [tupa1250], ISO 639-3 [tpr]) is spoken by 350 individuals in two reservations, Terra Indígena Rio Branco and Terra Indígena Rio Guaporé (Singerman 2018: 1). Mekéns (= Sakirabiat, Sakurabiat; Glottocode [saki1248], ISO 639-3 [skf]) is spoken by 14 individuals in the Terra Indígena Rio Mekéns (Galucio \& Nogueira 2018: 96). ${ }^{1}$ It is subdivided into three dialects, including Sakurabiat/Guarategayat, Guaratira, and Siokweriat (= Kampé, now spoken by just one individual). Akuntsú (Glottocode [akun1241], ISO 639-3 [aqz]) is spoken by three individuals near the Omerê creek (Aragon \& Tavares 2019). Makurap (Glottocode [maku1278], ISO 639-3 [mpu]) is spoken by ca. 50 individuals in the Terra Indígena Guaporé (Galucio \& Nogueira 2018: 96).

Until recently, the languages of the Tuparian branch had remained severely underdocumented. Tibor Sekelj documented short wordlists of Tuparí and Makurap during his 1948 expedition to the Rio Branco (Sekelj 1948). Emil-Heinrich Snethlage traveled around the region in 1933-4 and made notes on all Tuparian languages except Akuntsú (Snethlage 2015). Wanda Hanke visited the Mekéns in 1949 and also made some notes on the language (Hanke et al. 1958). Franz Caspar stayed with the Tuparí for several months in 1948 and 1955; based on his fieldnotes, a grammar sketch was prepared in 1958 (translated into Portuguese and published as Rodrigues \& Caspar 2017). ${ }^{2}$ Fortunately, the situation has improved drastically over the last 30 years due to a documentation boom in Amazonian linguistics. The following recent works have been prioritized as primary sources of lexical data used in this study. For Wayoró, we rely on the works by Nogueira (2011, 2015, 2019). For Tuparí, we give preference to Singerman's (2018) dissertation and to Alves's (2004) dictionary (especially when it comes to the position of the stress). As for Mekéns, Galucio's (1994, 2001, 2002, 2011a,b, 2014; Galucio et al. 2017; Alves \& Galucio 2007) works have been consulted for the Sakurabiat and Guaratira dialects, whereas for the Siokweriat dialect the short appendix in Aragon (2014) was used. This latter work has also been our primary source for Akuntsú, though earlier works by the same author (Aragon \& Carvalho 2007, Aragon 2008) as well as Gabas Jr. (2005) were also consulted. Finally, for Makurap we rely on Braga $(1992,2005)$ as well as on unpublished recordings by Denny Moore (collected in 2003 with the help of the consultant Alcides Makurap). In addition, lexical material has been extracted from the comparative works on Tuparian (presented below) whenever the relevant forms are not attested in our primary sources. For kinship terms in all Tuparian languages, we rely on Nogueira et al. (2019).

To this moment, however, few works have been dedicated to the phonological reconstruction of Proto-Tuparian. ${ }^{3}$ Moore \& Galucio (1994) offer a pioneering proposal of the segmental

${ }^{1}$ Although the language has been increasingly referred to as Sakurabiat in recent literature, here we reserve the label Sakurabiat for the dialect spoken by the Sakurabiat and Guarategayat groups. In contrast, the label Mekéns is used in a broader sense throughout this paper and covers the varieties spoken by the Guaratira and the Siokweriat (in addition to the one spoken by the Sakurabiat and the Guarategayat).

2 Other premodern sources on specific Tuparian languages include Anonymous (n/d, on Wayoró, apud Loukotka 1963: 46-7), Becker-Donner (1955, on Mekéns, apud Loukotka 1963: 48), Xerez (1946, on Makurap), and LéviStrauss (n/d, on the Kabišiana variety of Mekéns, apud Loukotka 1963: 48 and Lévi-Strauss 1950; see Nikulin submitted for the identification of Kabišiana as a Mekéns variety). We were unable to access any of these works.

${ }^{3}$ Aragon \& Cabral (2005) and Gabas Jr. (2005) also discuss the genetic relations within the Tuparian family (with special attention to the position of Akuntsú), but no claim is made with respect to the phonological reconstruction. Galucio \& Nogueira (2018) reconstruct the evolution of the object focus construction in the Tuparian 
phonology of Proto-Tuparian, which is based on a total of 124 cognate sets representing Wayoró, Tuparí, Mekéns, and Makurap; the respective reconstructed forms are also provided. Galucio \& Nogueira's (2012) work by and large reinforces Moore \& Galucio's (1994) reconstruction, differing from it mainly in that (i) the segment ${ }^{*} n d(z)$ is removed from the reconstructed inventory; (ii) the phonological status of ${ }^{*} b$ as a contrastive segment, treated as uncertain in Moore \& Galucio (1994), is confirmed; (iii) the data of a fifth Tuparian language, Akuntsú, are taken into account. Furthermore, Galucio \& Nogueira (2012) argue that the Proto-Tuparian segment * $D$ (the ad hoc symbol used in Moore \& Galucio 1994) should be interpreted as a voiced denti-alveolar stop * ${ }^{*}$. Galucio \& Nogueira (2012) also address the reconstruction of aspects of Proto-Tuparian morphosyntax, including the person inflection and the morphosyntactic alignment, as well as derivational morphology. Due to the nature of the publication, the segment reconstructed by Galucio \& Nogueira (2012) as * $d$ is the only one to be supported with detailed discussion and examples. The cognate sets that were used to substantiate the reconstruction of all other segments are not presented. That way, the only published work on the phonology of Proto-Tuparian in which the reconstructed phonemes are illustrated with actual linguistic data is Moore \& Galucio (1994), which predates the documentation boom of the Tuparian languages by a large margin.

An in-depth study of the historical phonology of the Tuparian group, besides being an interesting subject by itself, is crucial for our understanding of the diachronic development of the entire Tupian family (cf. Galucio \& Nogueira 2018: 95). Although there have been pioneering attempts at a phonological reconstruction of Proto-Tupian (Rodrigues 2002, 2005, 2007), most subgroups of Tupian have been represented in them by one single contemporary language (Tuparí for the Tuparian group, Mundurukú for the Mundurukú group, Yudjá for the Juruna group) rather than by the respective intermediate proto-languages (with the notable exception of Proto-Tupí-Guaraní). In other words, the comparative method has never been consistently applied to the Tupian family in a bottom-up manner. The situation, however, is likely to change in the near future, thanks to several recent and ongoing detailed, methodologically sound diachronic studies of low-level branches of Tupian (most recently Meira \& Drude 2015 for Proto-Mawé-Guaraní, Carvalho 2019 for Proto-Juruna, Picanço 2019 for ProtoMundurukú, Carvalho forthc. for Proto-Tupí-Guaraní). In this sense, this paper aims to contribute to the emergent field of diachronic Tupian studies in general by reconstructing parts of the consonantal system of Proto-Tuparian in some detail.

The International Phonetic Alphabet is used for representing data in this paper, with the

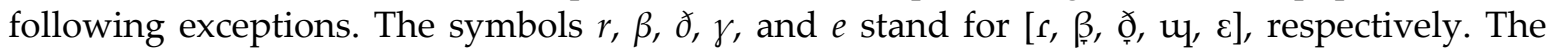
coda consonants are considered to be underspecified for features other than place of articulation in all Tuparian languages (cf. Singerman 2016 for Tuparí). Underspecified labial, dental/ alveolar, palatal, and velar consonants in coda are represented in small caps: $P, T, C, K$ (cf. a similar analytical decision for another Tupian language, Awetí, in Drude 2009). The acute accent denotes stress in Tuparí and Akuntsú and high tone in Makurap. ${ }^{4}$

languages. Nogueira et al. (2019) is an in-depth study of the Tuparian kinship terms, which also includes reconstructed forms; the phonological reconstruction in this work does not differ substantially from that of Galucio \& Nogueira (2012).

${ }^{4}$ The evidence for two level tones in Makurap (high and low) comes from our preliminary analysis of the Makurap recordings by Moore, wherein most words are conveniently accompanied by their whistled equivalents (cf. Moore \& Galucio 1994: 122). The high tone occurs at most once in polysyllables, and its position interacts with

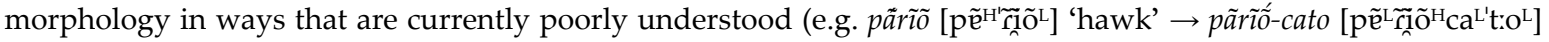
'harpia'). We do not mark the low tone explicitly. Makurap tokens taken from printed sources which do not transcribe the tonal distinctions (such as Braga 1992, 2005) are underlined. 
The remainder of this paper is structured as follows. In section 2, we present some evidence for the subgrouping of the Tuparian group accepted in this paper. In section 3 , we present the comparative evidence which supports the reconstruction of the approximant series for Proto-Tuparian as well as for the proto-languages of shallower genetic units, such as ProtoCore Tuparian and Proto-Corumbiara, and for an earlier stage of Wayoró. Specific sound changes required by our proposal are summarized in section 4 . We conclude by a succinct discussion of our findings in section 5 , followed by a list of abbreviations used in this paper.

\section{Internal classification of the Tuparian group}

In this section, we present evidence for a specific proposal regarding the subgrouping of the Tuparian group. Namely, we claim that (i) Wayoró and Tuparí form a subgroup to the exclusion of other languages ("Wayoró-Tuparí"), (ii) Mekéns and Akuntsú likewise form a subgroup to the exclusion of other languages ("Corumbiara"), and (iii) all the aforementioned languages form a clade ("Core Tuparian") to the exclusion of Makurap.

Makurap vs. Core Tuparian. The claim regarding the binary split of Proto-Tuparian into Makurap and Core Tuparian has found extensive support in a number of published works (cf. the lexicostatistical assessment in Galucio \& Nogueira 2012, Galucio et al. 2015: 238), even though little space has been allocated so far to the identification of innovations shared by the Core Tuparian languages. The most characteristic of them are listed below.

One such innovation appears to have affected the third person inflection pattern of the */j/-initial stems. In Makurap, a significant number of stems inflect for the third person by replacing their initial consonant ( $c$ - in oral environments; $n$ - is nasal environments) with another consonant ( $t$ - both in oral and nasal environments), as in ceK 'house.POSs', $n \tilde{a} c$ 'tooth' $\rightarrow t-e K$ 'his/her house', $t$ - $\tilde{a} c$ 'his/her tooth' (Braga 2005). ${ }^{5}$ A plausibly cognate pattern is found in Tupian languages outside the Tuparian group, such as Mundurukú (dək-\{á, nãj $\rightarrow t$-ək-\{á, $t$-ãj; Picanço 2005), Kuruaya ( $(-\rightarrow t-)$, Sateré-Mawé $\left(s^{-} \rightarrow h-\right)$, and most Tupí-Guaraní languages $\left({ }^{*} t-{ }^{*}-r-\rightarrow{ }^{*} t s-\right)$. This allows us to project the pattern attested in Makurap onto the ProtoTuparian level (we reconstruct PTpr ${ }^{*} j^{*} /{ }^{*} n-{ }^{*} C^{-}$, where ${ }^{*} n$ is the nasal allophone of ${ }^{*} / \mathrm{j} /$ ). All other Tuparian languages lost the archaic prefix ${ }^{*} c^{-}$and now use reflexes of PTpr ${ }^{*} i$ - in this function. For example, the third person of PTpr *jazip 'son, fraternal nephew (male ego)' (> Makurap $\underline{\text { caip }}$ ) is reconstructed as ${ }^{*}$ c-åip (> Makurap $\underline{\text { t-aip}}$ ). In Proto-Core Tuparian, the un-

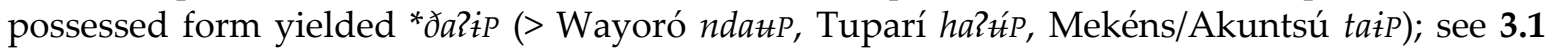
for PTpr ${ }^{*} j>$ Proto-Core Tuparian ${ }^{*}$. However, the third person form was not preserved as

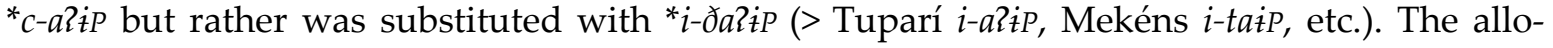
morph ${ }^{*} i$ - must have been extended through analogy from other consonant-initial stems.

Another clear innovation that identifies Core Tuparian as a valid genetic unit is the nasalization of the stops ${ }^{*} p$ and ${ }^{*} t$ in syllables with nasal nuclei, as shown in Table 1.

In turn, Core Tuparian is subdivided, in a binary manner, into Mekéns-Akuntsú and Wayoró-Tuparí. The former claim seems to be universally accepted (Gabas Jr. 2005; Galucio \& Nogueira 2012), as Mekéns and Akuntsú are remarkably close to each other and are reported to be mutually intellegible (Galucio et al. 2015: 237-8 even suggest that they are "co-dialects of the same language"). We propose the label Corumbiara for the clade which comprises Mekéns

${ }^{5}$ Braga $(1992,2005)$ transcribes the palatal obstruent of Makurap as $t \int$. In Moore's field recordings of Makurap, we found its pronunciation closer to [c] or [cç]. Throughout this paper, it will be represented as $c$. 


\begin{tabular}{|c|c|c|c|c|c|c|}
\hline PTpr & gloss & Wayoró & Tuparí & Mekéns & Akuntsú & Makurap \\
\hline $\begin{array}{c}{ }^{*} p \tilde{a} T- \\
* p \tilde{a} T-2 a-\end{array}$ & $\begin{array}{l}\text { to be tied } \\
\text { to tie }\end{array}$ & - & - & - & $\begin{array}{c}- \\
m \tilde{a} r a-\end{array}$ & $\begin{array}{l}\text { pãT- } \\
\text { pãrã- }\end{array}$ \\
\hline${ }^{*} p \tilde{\imath}: T$ & $\begin{array}{l}\text { humming- } \\
\text { bird }\end{array}$ & $\begin{array}{c}m \tilde{\imath} T \\
m \tilde{\imath}: T \text { 'penis' }\end{array}$ & $m \tilde{\imath}: T$ & - & $m \tilde{\imath}: T$ & $p \tilde{\imath} T$ \\
\hline *ãrãpĩra & woman & ãrãmĩra & ãrämũrã & ãrãmĩra & ãrãmiีrã & ${\underline{\tilde{a} r a \tilde{p} \tilde{\imath} j \tilde{a}^{6}}}^{6}$ \\
\hline${ }^{*}-p \tilde{a} \tilde{a}^{7}$ & knee & $\{k \tilde{\mathcal{t}}\} m \tilde{\imath} \tilde{a}$ & $m \tilde{\imath} \tilde{a}\{K-2 \tilde{a}\}$ & $\begin{array}{c}\{\text { nêkiwa\}minna } \\
\text { 'elbow's }\end{array}$ & $\{a\} m i n n \tilde{a}$ & $\{k a\}$ pĩa \\
\hline${ }^{*} p \tilde{a} r \tilde{\imath}(\tilde{o})$ & harpia & - & ротใa-mãri & - & - & pấrĩ $\{\tilde{o}\}$ \\
\hline${ }^{*} t \hat{\imath}^{9}$ & ashamed & $n \tilde{l}^{-}$ & $n \tilde{\imath}-$ & - & - & - \\
\hline${ }^{*} a t \tilde{t} P$ & head & - & 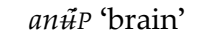 & $\operatorname{anz\tilde {t}P}$ & anẫP & át $t \tilde{t} P$ 'hair' \\
\hline${ }^{*} t \tilde{i} K-10$ & to weave & $n \tilde{\imath} K-$ & $n \tilde{\imath} K-$ & $n \tilde{\imath}-a$ & $n \tilde{\imath}-a$ & tĩK- \\
\hline${ }^{*} t \tilde{\imath} K^{11}$ & spotted & $n \tilde{\imath} K \sim n \tilde{\imath} K$ & $n \tilde{\imath} K$ & - & nĩK 'striped' & - \\
\hline${ }^{*} t \tilde{\imath}(:) K$ & timbó vine & $n \tilde{\imath}: K$ & $n \tilde{\imath}(:)_{K}$ & - & - & tĩK \\
\hline${ }^{*}$ at $\tilde{\imath} K^{12}$ & worm & $\operatorname{anĩK}$ & $\begin{array}{l}\text { anî́ 'leishma- } \\
\text { niasis ulcer' }\end{array}$ & Sio $a n \tilde{\imath} K$ & $\operatorname{an\tilde {\imath }P}$ & atĩK \\
\hline
\end{tabular}

Table 1. Nasalization of ${ }^{*} p,{ }^{*} t$ in the Core Tuparian languages in nasal environments

and Akuntsú. As for Wayoró and Tuparí, the special proximity between these two languages has been suggested in Galucio et al. (2015) based on an application of two distance-based algorithms to the 100-word Swadesh lists of the Tupian languages (83.7\% confidence rate), but this result was not replicated for other datasets considered in the cited work. In what follows, we identify several shared innovations which support the validity of both branches (Corumbiara and Wayoró-Tuparí).

Corumbiara. The Corumbiara languages (Mekéns and Akuntsú) share multiple lexical innovations which are unique to these two languages. The following are some examples thereof:

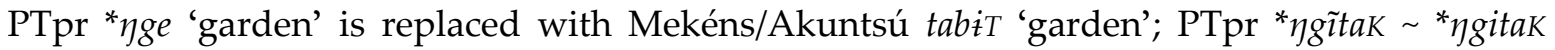
'night' is replaced with *matso (Mekéns mãtso\{pi\}, Akuntsú mãtfo); PTpr *mãñ 'manioc' is replaced with *taPjVT (Mekéns taPtsit, Akuntsú taPtoT); PTpr *ekiP 'arrow' is replaced with *mãpi

${ }^{6}$ The correspondence between Core Tuparian ${ }^{*} r$ and Makurap $j$ is not known to be regular.

${ }^{7}$ Hereinafter, the curled brackets denote material which is deemed not to be cognate despite not being demonstrably segmentable in the contemporary languages.

${ }^{8}$ The form is tentatively phonologized based on Snethlage's (2015: 518) attestation of 〈kina kiwamínja〉 'Ellbogen' (likely the first person inclusive ki-\{nēkiwa\}mĩna).

9 This root appears to have been lost in Makurap, unless mẽtiã 'ashamed' (Braga 2005: 191) is somehow related. A voiceless dental stop is reconstructed in light of the external cognates (Proto-Mawé-Guaraní *tĩ 'ashamed', Meira \& Drude 2015: 292).

${ }^{10}$ In Mekéns and Akuntsú, the only attested forms of these verbs contain the theme vowel $-a$, which triggers the deletion of the stem-final $-K$. The underlying stem is expected to have the shape nĩ $K$ - in both Corumbiara languages, but the forms that could prove it have not been attested in the published works.

${ }^{11}$ No cognate is attested in Makurap. A voiceless dental stop is reconstructed in light of the external cognates, such as Sateré-Mawé tĩK 'spotted' (Ribeiro 2010: 87).

12 The Mekéns reflex is attested as atĩ in Galucio et al. (2015: 266) but not in other sources on the language that we consulted. If the existence of this form is confirmed, it could be explained as a borrowing from Makurap atĩK or from Karo atĩ $\eta$, attested ibidem (the Makurap reflex is given there as atĩ, which must be a mistranscription, cf. Braga 2005: 184 and Moore's field data). Note that Akuntsú - $P$ does not regularly continue PTpr *-K. 
'arrow' (likely from Kwaza mãbi or Kanoê mapi; cf. Voort 2005: 386). Some further examples of lexical isoglosses specific to the Corumbiara languages are *tsaro 'yellow', *pi(:)K 'black', and *kicpiT 'fish', though we have been unable to provide an unequivocal Proto-Tuparian reconstruction for these specific concepts. In addition, the Corumbiara languages share multiple phonological innovations, some of which are exclusive to this subgroup (e.g. PTpr ${ }^{*} t{ }^{*} n d>{ }^{*} t s>$ Mekéns ts, Akuntsú tf; PTpr ${ }^{*} j{ }^{*} c>{ }^{*} t>$ Mekéns $t$, Akuntsú $t$; PTpr ${ }^{*} i(2) V>{ }^{*} i j V>$ Sakurabiat itsV, Guaratira/Siokweriat $i V$, Akuntsú itV). Most phonological innovations that characterize the languages of the Corumbiara branch will be discussed in more detail in section 3 .

Wayoró-Tuparí. Wayoró and Tuparí are not as tightly related to each other as Mekéns and Akuntsú, but nevertheless clear innovations shared exclusively by these two languages can be identified. For example, PTpr *mbo-ape 'fingernail' and *ojaT 'fire', whose reflexes are found in Makurap, Mekéns, and Akuntsú, are replaced with Proto-Wayoró-Tuparí *kĩrinã 'fingernail' and *akop-k-aP 'fire', respectively (the latter is evidently an *-aP nominalization from a verbal derivative of *akoP 'hot'). Wayoró and Tuparí are also unique in that they have high central rounded vowels / $\mathfrak{u} \tilde{\mathfrak{t}} /$ (Alves 2004: 41; Singerman 2016: 456; Nogueira 2019: 10), which correspond to /i $\tilde{\mathbf{i}} /$ in Mekéns, Akuntsú, Makurap, and many Tupian languages outside the Tuparian branch. In both languages, $/ \mathrm{u}$ i/ pattern together in that they make up the environment for at least one phonological process (the diachronic assibilation ${ }^{*} t>s \_\mathfrak{u}, \mathrm{i} /$ in Tuparí; the morphophonological dissimilation /e/ $\rightarrow a \_/ \mathfrak{u}, \mathrm{i} /$ in Wayoró, cf. Nogueira 2015).

\section{Proposal}

In this section, we present the evidence which supports the reconstruction of the approximant series in Proto-Tuparian (3.1). We will also show how innovative approximants arose from various sources through multiple independent innovations in individual Tuparian languages (from non-syllabic vowels, 3.2), in early Wayoró (from postoralized nasals, 3.3), and in ProtoCorumbiara (3.4, as hiatus-filling glides). Note that in the contemporary Tuparian languages most of the segments under discussion have changed to some other sounds (either through fortition or through lenition). For example, PTpr *eji 'marico bag' and *wawo 'sweet potato' are reflected as Wayoró endut, $\eta g^{w} a g o$; Tuparí éu, wáo; Mekéns eti, $k^{w} a(:) k o$; Akuntsú etí, $k^{w} a k o ́ ;$ Makurap éci, ßaßó. For now, these examples should suffice to give the reader a flavor of the trends in the evolution of the approximants in the individual histories of the Tuparian languages. A detailed discussion thereof is deferred to section 4 .

Note that in this paper we do not discuss the consonants that arose from combinations of an underspecified consonant in the coda position followed by an onsetless or a 2-initial syllable. In these environments, codas are commonly resyllabified as onsets in the contemporary Tuparian languages, which is usually accompanied by lenition (Braga 1992: 63-4 for Makurap; Galucio 1994: 991-2, 2001: 23 for Mekéns; Singerman 2018: 372-3, 378-80 for Tuparí, among others). An investigation of the approximants that may have developed in some languages through resyllabification of codas lies beyond the scope of this paper.

In Table 2, we summarize our proposal regarding the development of the Proto-Tuparian onsets in oral environments. Note that ${ }^{*}[\mathrm{mb}],{ }^{*}[\mathrm{nd}]$, and *[ng] are held here to be allophones of underlying $* / \mathrm{m} \mathrm{n} \mathrm{y} /$ in oral environments (see 3.3).

In Table 3, we summarize our proposal regarding the development of the Proto-Tuparian onsets in nasal environments. Note that ${ }^{*}[n]$ is held here to be the nasal allophone of an underlying $* / \mathrm{j} /$. 


\begin{tabular}{|c|c|c|c|c|c|c|c|c|}
\hline PTpr & Mak & PCT & pre-PCor & Mek/Aku & PWT & Tup & pre-Way & Way \\
\hline${ }^{*} \mathrm{p}$ & $\mathrm{p}$ & *p & \multirow{2}{*}{${ }^{*} \mathrm{p}$} & \multirow{2}{*}{$\mathrm{p}$} & ${ }^{*} \mathrm{p}$ & \multirow{3}{*}{$\underset{\text { s-/-PS-A }}{p}$} & *p & $\mathrm{p}$ \\
\hline${ }^{*}[\mathrm{mb}]$ & {$[\mathrm{mb}]$} & ${ }^{*} \mathrm{~b}$ & & & $* \mathrm{*}$ & & \multirow{2}{*}{$* \beta$} & \multirow{2}{*}[\mathrm{mb}]{$-/-\beta-$} \\
\hline$* \beta$ & $\mathrm{p}$ & $* \beta$ & $* b$ & $\mathrm{~b}$ & $D_{1}$ & & & \\
\hline${ }^{*} t$ & $\mathrm{t}$ & ${ }^{*} t$ & \multirow{2}{*}{${ }^{*} t$} & \multirow{2}{*}{$\begin{array}{c}\text { Mek ts, } \\
A k u \text { t }\end{array}$} & ${ }^{*} t$ & \multirow{2}{*}{$\mathrm{t}, \mathrm{s}^{\mathrm{B}}$} & $*_{t}$ & $\mathrm{t}$ \\
\hline${ }^{*}[\mathrm{nd}]$ & [nd] & $* d$ & & & ${ }^{*} \mathrm{~d}$ & & \multirow{2}{*}{ *ð } & \multirow{2}{*}{ [nd] } \\
\hline${ }^{*} \mathrm{j}$ & c & *ठ & $* d$ & \multirow{2}{*}{$\mathrm{t}$} & *ठ & h-/- $\varnothing-$ & & \\
\hline${ }^{{ }^{*} \mathrm{C}}$ & $t$ & ${ }^{*} \mathrm{C}$ & ${ }^{*} \mathrm{C}$ & & ${ }^{*} \mathrm{C}$ & $\varnothing$ & $* \mathrm{t} \int$ & t $\int$ \\
\hline${ }^{*} \mathrm{k}$ & k & ${ }^{*} \mathrm{k}$ & \multirow{2}{*}{${ }^{*} \mathrm{k}$} & \multirow{2}{*}{$\mathrm{k}$} & ${ }^{*} \mathrm{k}$ & \multirow{2}{*}{$\mathrm{k}$} & ${ }^{*} \mathrm{k}$ & k \\
\hline *[ng] & [ng] & ${ }^{*} \mathrm{~g}$ & & & ${ }^{*} \mathrm{~g}$ & & ${ }^{*} \mathrm{\gamma}$ & [ng] \\
\hline${ }^{*} \mathrm{~W}$ & $\beta$ & ${ }^{*} \mathrm{~W},{ }^{*} \mathrm{~V}^{\mathrm{C}}$ & ${ }^{*} \mathrm{~g}^{\mathrm{w}},{ }^{*} \mathrm{~g}^{\mathrm{C}}$ & $\mathrm{k}^{\mathrm{w}}, \mathrm{k}^{\mathrm{c}}$ & ${ }^{*} \mathrm{~W},{ }^{*} \mathrm{~V}^{\mathrm{C}}$ & $\mathrm{w}, \emptyset \mathrm{c}$ & ${ }^{*} \mathrm{~W},{ }^{*} \mathrm{\gamma}^{\mathrm{C}}$ & $\begin{array}{c}{\left[\mathrm{ng}^{\mathrm{w}}\right],[\mathrm{ng}]^{\mathrm{c}}} \\
\text { Кир } \beta\end{array}$ \\
\hline${ }^{*} \mathrm{r}$ & $\mathrm{r}$ & ${ }^{*} \mathrm{r}$ & ${ }^{*} \mathrm{r}$ & $\mathrm{r}$ & ${ }^{*} \mathrm{r}$ & $\mathrm{r}$ & ${ }^{*} \mathrm{r}$ & $\mathrm{r}$ \\
\hline$* 3$ & $3 \sim \varnothing$ & ${ }^{*}+$ & ${ }^{*} 2 \sim{ }^{*} \varnothing$ & $3 \sim \varnothing$ & *? & $?$ & ${ }^{*} 2 \sim{ }^{*} \varnothing$ & $? \sim \varnothing$ \\
\hline
\end{tabular}

A $=$ before $i$; ${ }^{\mathrm{B}}=$ before $i$ or $\mathfrak{u}$; $\mathrm{C}=$ before a rounded vowel

Table 2. Proto-Tuparian onsets and their reflexes in oral environments

\begin{tabular}{|c|c|c|c|c|c|c|c|c|}
\hline PTpr & Mak & PCT & pre-PCor & Mek/Aku & PWT & Tup & pre-Way & Way \\
\hline${ }^{*} \mathrm{p}$ & $\mathrm{p}$ & \multirow{2}{*}{${ }^{*} \mathrm{~m}$} & \multirow{2}{*}{${ }^{*} \mathrm{~m}$} & \multirow{2}{*}{$\mathrm{m}$} & \multirow{2}{*}{${ }^{*} \mathrm{~m}$} & \multirow{2}{*}{$\mathrm{m}$} & \multirow{2}{*}{${ }^{*} \mathrm{~m}$} & \multirow{2}{*}{$\mathrm{m}$} \\
\hline${ }^{*} \mathrm{~m}$ & $\mathrm{~m}$ & & & & & & & \\
\hline$* t$ & $\mathrm{t}$ & \multirow{2}{*}{${ }^{*} \mathrm{n}$} & \multirow{2}{*}{${ }^{*} \mathrm{n}$} & \multirow{2}{*}{$\mathrm{n}$} & \multirow{2}{*}{${ }^{*} \mathrm{n}$} & \multirow{2}{*}{$\mathrm{n}$} & \multirow{2}{*}{${ }^{*} \mathrm{n}$} & \multirow{2}{*}{$\mathrm{n}$} \\
\hline${ }^{*} \mathrm{n}$ & $\mathrm{n}$ & & & & & & & \\
\hline$*[n]$ & $\mathrm{n}$ & $* n$ & $\mathrm{n}$ & $\mathrm{n}$ & $* n$ & $\mathrm{n}, \emptyset^{\mathrm{A}}$ & ${ }^{*} \mathrm{n}$ & n \\
\hline${ }^{*} \mathrm{C}$ & $\mathrm{t}$ & $?^{13}$ & $?$ & $?$ & $?$ & $?$ & $?$ & $?$ \\
\hline${ }^{*} \mathrm{k}$ & $\mathrm{k}$ & ${ }^{*} \mathrm{k}$ & \multirow{2}{*}{${ }^{*} \mathrm{k}$} & \multirow{2}{*}{$\mathrm{k}$} & ${ }^{*} \mathrm{k}$ & \multirow{2}{*}{$\mathrm{k}$} & ${ }^{*} \mathrm{k}$ & $\mathrm{k}$ \\
\hline${ }^{*}$ ng & ng & ${ }^{*} \mathrm{~g}$ & & & ${ }^{*} \mathrm{~g}$ & & ${ }^{*} \mathrm{X}$ & $\mathrm{y}$ \\
\hline${ }^{*} \mathrm{~W}$ & $\mathrm{~m}$ & ${ }^{*} \mathrm{~W},{ }^{*} \mathrm{\gamma}^{\mathrm{B}}$ & ${ }^{*} \mathrm{~g}^{\mathrm{W}},{ }^{*} \mathrm{~g}^{\mathrm{B}}$ & $\begin{array}{c}\mathrm{k}^{\mathrm{w}}\left(S a k \mathrm{n}^{\mathrm{w}}\right) \\
\mathrm{k}(S a k \mathrm{n})^{\mathrm{B}}\end{array}$ & ${ }^{*} \mathrm{~W},{ }^{*} \mathrm{\gamma}^{\mathrm{B}}$ & $\mathrm{w}, \emptyset^{\mathrm{B}}$ & ${ }^{*} \mathrm{~W},{ }^{*} \mathrm{\gamma}^{\mathrm{B}}$ & $\mathrm{n}^{\mathrm{w}}, \mathrm{n}^{\mathrm{B}}$ \\
\hline${ }^{*} \mathrm{r}$ & $r$ & ${ }^{*} \mathrm{r}$ & ${ }^{*} \mathrm{r},{ }^{*} \mathrm{n}^{\mathrm{C}}$ & $\mathrm{r}, \mathrm{n}^{\mathrm{C}}$ & ${ }^{*} \mathrm{r}$ & $\mathrm{r}$ & ${ }^{*} \mathrm{r}$ & $\mathrm{r}$ \\
\hline$* ?$ & $? \sim \varnothing$ & $* ?$ & $\left.{ }^{*}\right\} \sim{ }^{*} \varnothing$ & $3 \sim \varnothing$ & $* ?$ & $?$ & ${ }^{*} 2 \sim{ }^{*} \varnothing$ & $? \sim \emptyset$ \\
\hline
\end{tabular}

A $=$ before $\tilde{\imath} ;{ }^{\mathrm{B}}=$ before a rounded vowel; $\mathrm{C}=$ between front vowels

Table 3. Proto-Tuparian onsets and their reflexes in nasal environments

13 Although PTpr *c certainly occurred in nasal environments (as in *mĩco 'curassow', 'c-ãc 'his/her tooth', ${ }^{*} \mathcal{c}$-ẽri 'his/her hammock' > Mak mĩtố, $t$-ã $c, t$-ẽrĩ), we have not identified reflexes of any of these word forms in any Core Tuparian language. 


\section{A note on the reconstruction of $\mathrm{PTpr}^{*} t$}

Although a detailed discussion of the reconstruction of Proto-Tuparian voiceless segments is beyond the scope of this paper, we deem it appropriate to briefly comment on our interpretation of the sound correspondence between Wayoró $t$, Tuparí $t\left(s \_\mathrm{i}, \mathrm{u} /\right)$, Mekéns ts, Akuntsú $t$, and Makurap t. Galucio \& Nogueira (2012) claim that the correspondence set in question "clearly reconstructs as the affricate ${ }^{*}$ ts, which becomes [+palatal] in Akuntsú, and loses the feature [+sibilant] in Wayoro, Makurap and Tupari, except before [i] in Tupari". ${ }^{14}$ We believe that the reconstruction should be amended to ${ }^{*} t$ for four reasons.

(i) First of all, reconstructing ${ }^{*} t s$ would imply an innovation $\left({ }^{*} t s>t\right)$ shared by Makurap, Tuparí, and Wayoró, though Makurap is not known to be closely related to Tuparí and Wayoró. No such problem arises if ${ }^{*} t$ is reconstructed; in this case, we would only need to assume that PTpr ${ }^{*} t$ yielded an affricate in the Corumbiara languages.

(ii) Note that what we reconstruct as *[nd] (the oral allophone of PTpr*/n/) also yielded an affricate in Mekéns/Akuntsú and $t$ ( $s$ before non-back high vowels) in Tuparí. In our current proposal, this is straightforwardly accounted for: all PTpr postoralized nasals $\left({ }^{*} m b,{ }^{*} n d,{ }^{*} \eta g\right)$ became voiced stops in Proto-Core Tuparian $\left({ }^{*} b,{ }^{*} d,{ }^{*} g\right)$, which subsequently merged with PTpr voiceless stops $\left({ }^{*} p,{ }^{*} t,{ }^{*} k\right)$ in the Corumbiara languages (yielding $\left.{ }^{*} p,{ }^{*} t s,{ }^{*} k\right)$ and in Tuparí $\left(p /(P)_{s}, t / s\right.$, $k)$. No elegant explanation of the sort is available if one accepts the reconstruction of PTpr ${ }^{*} t s$.

(iii) There is no competing identity correspondence that could potentially involve PTpr ${ }^{*} t$ in onsets, except for two isolated etymologies: 'chicha' (Wayoró tzero, Mekéns tiero, Akuntsú tieró) and 'daughter' (Tuparí haK, Wayoró, Mekéns, Akuntsú, Makurap taK). The former item is a Wanderwort (compare Arikapú tfuero, Kanoê tsero; Voort 2005: 381, fn. 28, 2007: 138, fn. 4) and is thus likely to have diffused into at least some of the Tuparian languages through horizontal transmission. As for the word for 'daughter', the correspondence is unique and thus cannot back up alone the reconstruction of PTpr ${ }^{*} t$. In fact, it is possible to reconstruct ${ }^{*}$ caK (no other examples for ${ }^{*} \mathrm{c}$ - in the word-initial position are known, so the reflexes $h$ - in Tuparí and $t$ in Wayoró could be regular).

(iv) Finally, the external correspondences of what we reconstruct as PTpr ${ }^{*} t$ are dental/alveolar stops throughout the Tupian family (Karitiana, Karo, Proto-Mawé-Guaraní $\left({ }^{*}\right) t$, Puruborá $d$, as well as $t$ alternating with $n$ in the Mondé languages), even though admittedly affricate reflexes are also attested in non-palatalizing environments in languages such as Yudjá $(t f-)$, Mundurukú (tf-/-d3-), Kuruaya (tf-) and Proto-Tupí-Guaraní $\left({ }^{*} t s{ }^{*} t\right)$ ). At least Proto-TupíGuaraní demonstrably innovated its affricate from Proto-Mawé-Guaraní *t, as shown not only by external comparanda (Meira \& Drude 2015) but also by the fact that the Proto-TupíGuaraní affricate ${ }^{*} t s$ changes to ${ }^{*} n d$ in the environment ${ }^{*} \tilde{V}_{-}$(cf. *tso 'to go' and its causative *mõ-ndo 'to send'). Together, all these facts point to Proto-Tupian *t as the probable ancestor of what we reconstruct as PTpr ${ }^{*} t$, making our reconstruction more credible. For examples and a detailed discussion of the reflexes of Proto-Tupian ${ }^{*} t$, see Nikulin and Carvalho (2019: 276-8).

\subsection{Proto-Tuparian approximants}

In this section, we justify the reconstruction of three approximant phonemes for ProtoTuparian: $* / \beta /, * / j /$, and $* / w /$. All of these appear to have been straightforwardly retained from Proto-Tupian ${ }^{*} \beta,{ }^{*} j$, and ${ }^{*} w$. Preceding nasal nuclei, ${ }^{*} / \mathrm{j} /$ was realized as a nasal stop ${ }^{*}[\mathrm{n}]$, which

${ }^{14}$ In fact, the sibilant reflex in Tuparí is conditioned not only by _ $i$, but also by _ $\mathcal{H}$ (as in $s \mathfrak{H T}$ 'peach palm', $s \mathcal{H} T$ 'to cook'< PTpr *tiT, ${ }^{*}$ tit-). 
is retained in all contemporary languages (unlike the oral allophone [j], which underwent major changes in all daughter languages; see below). In our reconstructions, we represent the allophones of ${ }^{*} / \mathrm{j} /$ as ${ }^{*} j$ and ${ }^{*} n$, respectively, in order to highlight the fact that their default reflexes in all daughter languages are so different from each other that they are no longer synchronically analyzed as allophones of the same phoneme. As for the labiovelar approximant $* / w /$, it is likely that it was phonetically nasalized in nasal environments (i.e., [w]]); this is, however, not represented in our reconstructions, because in most contemporary languages the reflexes of ${ }^{*}[w]$ and ${ }^{*}[\tilde{w}]$ are reasonably similar to each other. The bilabial approximant $* / \beta /$ is not attested in nasal environments, which may be a spurious gap, given that $* / \beta /$ is an extremely rare segment in our corpus.

All Proto-Tuparian approximants, with the exception of the nasal allophone of $/ \mathrm{j} /$, were frequent targets of multiple fortition (and, to a lesser degree, lenition) processes, which operated in the history of each contemporary language to differing extents. These will be systematized in section 4 . Nevertheless, the directionality of each sound change can be quite securely identified thanks to converging internal and external evidence, so that in each case one can be sure that the segments in question were indeed articulated as approximants in ProtoTuparian. In subsections 3.2-4, we will discuss a number of correspondence sets for which the contrary holds: segments other than approximants (such as nasal stops or high vowels) are reconstructed for Proto-Tuparian, and it is shown that they gave rise to innovative approximants in specific languages or subgroups of Tuparian.

PTpr ${ }^{*} \beta$. In Table 4, we show both secure etymologies which instantiate PTpr ${ }^{*} \beta$. The original articulation is preserved in Wayoró only. In Tuparí and Makurap, PTpr ${ }^{*} \beta$ merged with PTpr ${ }^{*} p$, yielding Tup $p$ (-PS- before $i$ ) and Mak $p$. In the Corumbiara languages, PTpr ${ }^{*} \beta$ is reflected as $b$. Despite the extreme scarcity of the relevant cognate sets, the reconstruction of $\operatorname{PTpr}^{*} \beta$ gains some credibility in light of the fact that it corresponds to Proto-Tupí-Guaraní ${ }^{*} \beta$, as in PTG *to $\beta a$ 'face' and *i itu 'wind' ( PTpr *je $\beta a$, *i i ijo; cf. Mello 2000: 183, 207). Note that PTG ${ }^{*} \beta$ is also a low-frequency segment (at least morpheme-internally): in Meira \& Drude's (2015) corpus of Mawé-Guaraní etymologies, it appears only in PTG *urußu 'vulture' ( PTpr *orop2o), *jaßoti 'tortoise' (no cognate in Tuparian), in the aforementioned *to $\beta a$ 'face' and *i $\beta i t u$ 'wind', as well as in *aßati 'maize', borrowed from a Cariban or other North Amazonian source (Rodrigues 1985: 389). ${ }^{15}$

\begin{tabular}{|c|c|c|c|c|c|c|}
\hline PTpr & gloss & Wayoró & Tuparí & Mekéns & Akuntsú & Makurap \\
\hline \multicolumn{7}{|c|}{ oral } \\
\hline${ }^{*} j e \beta a$ & $\begin{array}{l}\text { forehead } \\
\text { CT only: }\end{array}$ & - & épa 'eye' & - & eba-pé & cépa \\
\hline *jeßа-јорар & eye (“jopap 'grain') & eßa-paP & - & eba-opaP & eba-páP & - \\
\hline${ }^{*} j e \beta a-p i$ & face ( ${ }^{*} p i$ 'inner') & - & épa-Psi & Sio eba-pi & $e b a-p i ́$ & - \\
\hline${ }^{*} i \beta i j o$ & wind & - & HPsió & - & - & - \\
\hline
\end{tabular}

Table 4. Proto-Tuparian $* / \beta /$ (oral ${ }^{*} \beta$, unattested in nasal environments)

In our current proposal, PTpr ${ }^{*} \beta$ is reflected as $p$ in Makurap, thus paralleling the fortition and devoicing of PTpr ${ }^{*} j$ to Makurap $c$ (see below). We have also considered an alternative

${ }^{15}$ In addition, Meira \& Drude (2015: 295) give PTG *taßa 'village', but a more correct reconstruction would be ${ }^{*} t a P$ (cf. Mello 2000: 195), of which ${ }^{*} t a \beta-a$ is an inflected form (the so called argumentative case). Its Tuparian cognate is *ja(:)P 'village'. Meira \& Drude (2015: 294) also note that PTG *ißõ 'to shoot' has a cognate in Awetí and reconstruct Proto-Awetí-Guaraní *(2)ìi õ , but no cognate is known in Sateré-Mawé. 
scenario, whereby PTpr ${ }^{*} \beta$ would have been regularly preserved in Makurap as $\beta$. This possibility is prompted by Nogueira et al.'s $(2019: 39,41)$ reconstruction of two kinship terms: PTpr * $a \beta i$ 'father (vocative)' (> Way $a \beta i$, Tup aPsí, Mek abi(-top), Mak á $\beta a$ ) and *aßatso 'grandfather' (> Way eßato, Mek abatso, Aku abatfó, Mak aßáto). Regarding the former term, note that Makurap $a$ is not a regular reflex of PTpr ${ }^{*} i$, which entails that Proto-Core Tuparian ${ }^{*} a \beta i$ is likely not to be cognate with Mak áßa. As for the term for 'grandfather', there is evidence that the reconstruction should be amended to *jop-ato (literally 'father-big'), with an irregular development of the root vowel ${ }^{*} o$ in all languages except in the Tuparí compound mẽPsir-ob-ató 'fatherin-law (female ego), lit. son's grandfather' (cf. håtP-b-ató 'father-in-law (male ego)', in which the same vowel was irregularly lost). That way, the bilabial approximant found in Way eßato or Mak aßáto arose through resyllabification of a coda ${ }^{*} P$. As noted above, we are not concerned with such resyllabified approximants in this paper for lack of space.

$\mathbf{P T p r} * / \mathbf{j} /$. The reader has already seen that we take PTpr ${ }^{*} j$ and ${ }^{*} n$ to be surface realizations of $\mathrm{PTpr}{ }^{*} / \mathrm{j} /$ in oral and nasal environments, respectively. While ${ }^{*} n$ retained its articulation in all daughter languages, ${ }^{*} j$ shows more divergent reflexes. We assume that it preserved its palatal articulation in Makurap but became a voiceless affricate in this language (thus, $\mathrm{PTpr}^{*} j>\mathrm{Mak} c$ ). In Proto-Core Tuparian, conversely, it appears to have preserved its manner of articulation but changed its place of articulation from palatal to dental (that is, $\mathrm{PTpr}^{*} \mathrm{j}>$ PCT ${ }^{*}$ ). ${ }^{16}$ In Wayoró, PCT ${ }^{*}$ became an underlying nasal stop /n/ (which surfaces as [nd] in oral environments), which parallels precisely other developments reconstructed for this language: PCT ${ }^{*} w>$ Way $/ \mathrm{n}\left({ }^{\mathrm{w}}\right) /$ (see below in this subsection), $\mathrm{PCT}^{*}{ }^{*}->$ pre-Way ${ }^{*} \beta->$ Way $/ \mathrm{m}-/$ (see 3.2), and $\mathrm{PCT}{ }^{*} i->$ pre-Way ${ }^{*} j->$ Way /n-/ (see 3.2). In Tuparí, one finds the reflex $h$ - wordinitially and $-\varnothing$ - word-internally. In the Corumbiara languages, PCT ${ }^{*} \partial$ became a homorganic stop $t$, as all other approximants $\left({ }^{*} \beta>b ;{ }^{*} w>k\left({ }^{w}\right) ;{ }^{*} j>\right.$ Mek $t$ s/Aku $t$; see this subsection and 3.4).

The correspondence Way $n d \sim$ Tup $h / \varnothing \sim$ Mek/Aku $t \sim$ Mak $c$ has not been previously claimed to continue the same underlying segment of Proto-Tuparian as the correspondence Way/Tup/Mek/Aku/Mak $n$. Important evidence for lumping them together comes not only from the fact that they occur in a complementary distribution (in oral vs. nasal environments, respectively), but also from the fact that their reflexes in Makurap show identical behavior when they occur as the initial segments of relational stems. Namely, both Mak $c$ - and $n$ - may derive relational stems from absolute ones (e.g. eK 'house', êrĩ 'hammock' $\rightarrow c-e K$ 'house.POss', n-ërĩ 'hammock.POSS'; Braga 2005: 48sqq.). In addition, whenever these segments occur in the beginning of a relational stem (either derived from an absolute stem or underived), they are replaced with the $3^{\text {rd }}$ person prefix $t$-. External evidence unequivocally shows that the correspondences Way nd $\sim \operatorname{Tup} h / \varnothing \sim$ Mek/Aku $t \sim$ Mak $c$, on the one hand, and Way/Tup/Mek/ $\mathrm{Aku} / \mathrm{Mak} n$, on the other hand, go back to a single consonant of Proto-Tupian. For example, in Karo, both correspond to $j$ (e.g. Proto-Tuparian *jajo 'armadillo', *jaote 'peccary', *ja(:)ko 'liz-

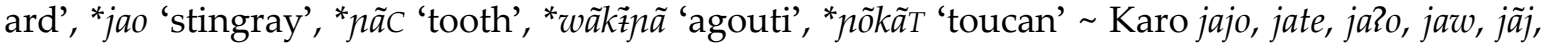
wakãja, jokãn; data from Gabas Jr. 1999). In Proto-Mundurukú, the regular correspondence is * (e.g. Proto-Tuparian *jajo 'armadillo', *jaote 'peccary', *ja(:)ko 'lizard', *jakeK 'army ant', * $n \tilde{a} \mathrm{C}$

${ }^{16}$ Note that unconditional dentalization of ${ }^{*} j$ to $\partial$ is known from the phonological histories of many Amazonian languages, such as Shiwilu (Kawapanan; Valenzuela Bismarck 2011: 279-80) and Guarasugwe (Tupí-Guaraní $<$ Tupian; Ramirez et al. 2017: 432). In Kubeo (Tukanoan), the reflex of Proto-Tukanoan * $j$ is realized as [ð] between non-high vowels (Chacon 2014: 65sqq). Several Cariban languages, such as Venezuelan Kari'ña, Pemón, and Makuxí, reflect Proto-Cariban *j as [ð] at least in some environments. We know of no Amazonian language in which an opposite development (i.e., ${ }^{*}>j$ ) would be claimed to have taken place in a non-palatalizing environment (an anonymous reviewer rightly remarks that outside the Americas, such a development is attested between vowels in many Turkic languages). This yields additional support for our hypothesis regarding PTpr *j> PCT * . 


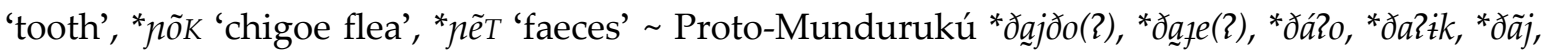

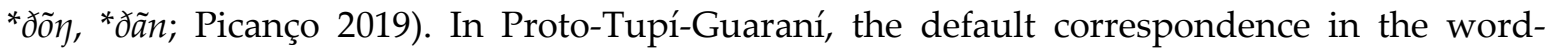
initial position is *t- (e.g. PTpr *jajo 'armadillo', *jakeK 'army ant', * $n \tilde{a} \mathrm{c}$ 'tooth', * $n \tilde{\sigma} K$ 'chigoe flea', *nõkãT 'toucan' PTG *tatu, *ta?oK, ${ }^{*} t \tilde{a} c,{ }^{*} t \tilde{u} K,{ }^{*} t \tilde{u} k \tilde{a} T ;$ cf. Mello 2000).

In Table 5, we list all known Proto-Tuparian tokens which instantiate PTpr ${ }^{*} j$ and do not show significant irregularities in the development of this consonant in the daughter languages.

\begin{tabular}{|c|c|c|c|c|c|c|}
\hline PTpr & gloss & Wayoró & Tuparí & Mekéns & Akuntsú & Makurap \\
\hline \multicolumn{7}{|c|}{ oral (> Proto-Core Tuparian ${ }^{*}$ ) } \\
\hline $\begin{array}{l}\text { *japo: } \\
\text { *jambo: }\end{array}$ & shimbillo (CT only) & - & hapó & tapo: & - & - \\
\hline${ }^{*}$ jajo ${ }^{17}$ & armadillo & ndato ${ }^{18}$ & - & tato & tató & - \\
\hline *ja(:)ko & lizard & - & hakó & ta:ko & - & cáko \\
\hline *jakeK ${ }^{19}$ & army ant & ? akeK & hakék\{e\} & takeK & - & - \\
\hline${ }^{*} j a \dot{t}^{20}$ & howler monkey & ndau & haú & $t a: 2 \dot{i}$ & tai-kóP & - \\
\hline$* j a o^{21}$ & stingray & - & - & - & - & cáo \\
\hline *jaote & peccary & - & haote-Zirí & taotse & taotfé & cáóte \\
\hline *jaP & hair, feather & ndaP & hap & taP & $a$-táP & caP \\
\hline${ }^{*} j a: P$ & village & - & ha:P & ta:P & - & $\mathrm{caP}$ \\
\hline${ }^{*}$ wejaP & anteater (CT only) & $\eta^{w} \tilde{e} n d a P$ & - & $k^{w} e t a P$ & witáp & - \\
\hline *jaT & snake & ndaT & hat & - & - & $c a T$ \\
\hline *jaT?a & bullet ant (WT only) & ndara & háT?a & - & - & - \\
\hline${ }^{*}$ ojaT & fire & - & - & otat & otáT & ócat \\
\hline *jac & $\begin{array}{l}\text { itchiness } \\
\text { (WT only) }\end{array}$ & $n d a c$ & $\begin{array}{c}p e-a ́ c \\
h a ́ c-k a \text { 'to scratch' }\end{array}$ & - & - & - \\
\hline
\end{tabular}

Table 5. Proto-Tuparian */j/ (oral *j, nasal $\left.{ }^{*} n\right)$ (to be continued)

17 Although no cognate in Makurap is known, PCT * ðaðo can be securely traced back to PTpr *jajo because precise external cognates are found all across Tupian (Karo and Puruborá jajo, Karitiana sosi, Proto-Mundurukú * ðajðo(2), Sateré-Mawé sahu, PTG *tatu; cf. Galucio et al. 2015: 262). Moore \& Galucio (1994: 132) give Makurap tayto (in our transcription, tacto), but we could not confirm the existence of this form in our main sources on Makurap; moreover, it does not correspond regularly to the remaning forms. Mekéns tato is attested by Moore \& Galucio (1994: 132) and Snethlage (2015: 520, ‘tatú〉 'Tatú (Gürteltier)').

18 The expected reflex of the intervocalic PTpr ${ }^{*} j$ would be ${ }^{*} n d$, not $t$. It is likely that that some sort of a dissimilation of the kind *NDVND .. > NDVD... applied in this word, as in * $\eta g^{w} a \eta g o>\eta g^{w} a g o$ 'sweet potato' (with an additional devoicing: ${ }^{*} n d>* d>t$; note that [d] is not part of the phonetic inventory of Wayoró).

${ }^{19}$ The expected reflexes in Wayoró and Tuparí would be Way *ndakeK, Tup *hakeK. We surmise that Way akeK was borrowed from an early form of Tuparí (or a variety close to it), whereas in Tuparí some sort of expressive reduplication could have applied. The Mekéns reflex is regular but is attested only in Hanke et al. (1958: 212) as

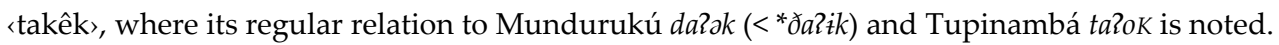

${ }^{20}$ Although no cognate in Makurap is known, PCT ${ }^{*}$ ðat can be securely traced back to PTpr *jai because a precise external cognate is found in Karo (jai 'howler monkey', Galucio et al. 2015: 267). The Wayoró reflex is also attested as ndeu (Nogueira 2015: 617). Akuntsú -koP stands for 'red'.

${ }^{21}$ Although no cognate in Core Tuparian is known, Mak cáo can be securely traced back to PTpr *jao because a precise external cognate is found in Karo (jaw 'stringray', Gabas Jr. 1999: 13). Galucio et al. (2015: 272) also cite possible cognates in Puruborá, Yudjá, and Xipáya. 


\begin{tabular}{|c|c|c|c|c|c|c|}
\hline PTpr & gloss & Wayoró & Tuparí & Mekéns & Akuntsú & Makurap \\
\hline *jarìP & $\begin{array}{c}\text { son, fraternal } \\
\text { nephew (male ego) }\end{array}$ & ndauP & harúP & taip & taip & $\frac{\text { caip }}{\text { 'sperm') }}$ \\
\hline${ }^{*} j O P$ & father & ndoP & $h o(:) P$ & toP & toP & $\mathrm{COP}$ \\
\hline $\begin{array}{l}{ }^{*} j o(:) P^{22} \\
*_{j o-a P}\end{array}$ & $\begin{array}{c}\text { to lie } \\
\text { hammock (CT) }\end{array}$ & $\begin{array}{l}n d o P- \\
n d o-a P\end{array}$ & $\begin{array}{c}- \\
o-a ́ P \sim w-a ́ P\end{array}$ & $\begin{array}{l}\text { to: } P- \\
\text { to- } a P\end{array}$ & $\begin{array}{l}\text { to- } a \\
\text { to- } a P\end{array}$ & - \\
\hline *joroP & that (sitting) & - & horoP & - & - & CO:P \\
\hline *jizi & two (CT only) & $n d \mathfrak{t u} \boldsymbol{t}-T$ & hurú 'pair' & tiri & tîri & - \\
\hline${ }^{*} j-e P$ & leaf.POSS ${ }^{23}$ & $n d e P$ & heP & teP & $t-e P$ & $c e P$ \\
\hline *jeT & name & ndet & heT & teT & teT & cet \\
\hline *jeTROP ${ }^{24}$ & rubber & - & heróP & - & tedó & $\underline{\text { coroP }}$ \\
\hline${ }^{*} j-e K$ & house.POSS & $n d-e K$ & $h-e K$ & $t-e K$ & $t-e K$ & $c-e K$ \\
\hline $\begin{array}{l}{ }^{*} j i: T \\
* j i: T-\{a\end{array}$ & $\begin{array}{c}\text { flower } \\
\text { flower (CT only) }\end{array}$ & $\begin{array}{c}\text { kHP-ndi:T } \\
\text { 'forest' } \\
\text { ndirr- } a\end{array}$ & $\begin{array}{c}\text { ? hí:T 'side dish' } \\
\text { híT-?a }\end{array}$ & tir- $a^{25}$ & tir-á & kiP-cír-eT \\
\hline *eji & marico bag & endut & éu & eti & etí & $e ́ c \dot{t}$ \\
\hline \multicolumn{7}{|c|}{ nasal (> Proto-Core Tuparian ${ }^{*} n$ ) } \\
\hline *na & mother (voc.) & $n \tilde{a}$ & $n \tilde{a}$ & $\tilde{a}-t s i^{26}$ & - & $n \tilde{a}$ \\
\hline *wãkżnã & agouti & $\eta^{w} \tilde{a} k \tilde{t} \eta \tilde{a}$ & - & 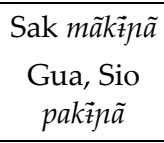 & pakã̃na & $m \tilde{a} k \tilde{t} \eta \tilde{a}$ \\
\hline${ }^{*} t a \tilde{a} \tilde{a}$ & earring (CT only) & tãna & - & - & tfãnã & - \\
\hline *kĩrĩna & nail (WT only) & kĩrĩna & kirĩna & - & - & - \\
\hline *nãc & tooth & nãc & $n \tilde{a} c$ & nãc & nãc & nãc \\
\hline${ }^{*}$ nõkãT & toucan & - & nõkấT & - & - & nốkãT \\
\hline${ }^{*}$ nõtaP & flea & - & nõtáP & - & - & nốtãP \\
\hline
\end{tabular}

Table 5. Proto-Tuparian */j/ (oral *j, nasal $\left.{ }^{*} n\right)$ (to be continued)

${ }^{22}$ Although no cognate in Makurap is known, PCT * ${ }^{\circ}(:) P$ can be securely traced back to PTpr *jo(:)P (as opposed to ${ }^{* *} n d o(:) P$ ) because a precise external cognate is found in Karo (jop- 'to live', Gabas Jr. 1999: 127). The noun *jo-aP 'hammock' is a nominalization of this verb ('lying place').

${ }^{23}$ In most Tuparian languages, the only known term for 'leaf' is synchronically an underived relational noun., with no absolute equivalent attested. However, in Akuntsú one finds both an absolute $(e P)$ and a relational $(t-e P)$ form (Aragon 2014: 130), which is symbolized here by a hyphen.

${ }^{24}$ The absence of a coda consonant in Akuntsú is irregular, as is the vowel $o$ in the initial syllable in Makurap.

25 The form is tentatively phonologized based on Snethlage's (2015: 520) attestation of <itíra> 'Blüte' (likely the third person i-tira). Hanke et al. (1958: 212) attests ‘ôtira> 'eyebrow' (o- is the 1sG prefix), which is likely a semantic offshoot of the same word. The semantic development from 'flower' to 'eyebrow' has also been reconstructed for the Macro-Jê language Maxakalí, where the compound $k y c-d y T$ 'eyebrow' means literally 'forehead flower' (mĩ-dyT 'flower', literally 'tree flower'); see Nikulin and Silva (2020: 56).

${ }^{26}$ The Mekéns vocative term for 'mother' is identified by Nogueira et al. (2019: 41) as a fossilized compound of the original vocative term for 'mother' (PTpr * $n \tilde{a}$ in our reconstruction) and the original referential term for 'mother' (PTpr *ti in our reconstruction, still found in Mekéns as tsi), paralleling Mekéns abi-toP 'father (voc.)' =abi 'father (voc.)' + toP 'father (ref.)'. Deriving the Mekéns form from PTpr *nã-t $i$ is unproblematic, because the loss of stem-initial $\mathrm{PTpr} * / \mathrm{j} /$ is a recurrent phenomenon regular in polysyllabic relational stems, see below. 


\begin{tabular}{|c|c|c|c|c|c|c|}
\hline PTpr & gloss & Wayoró & Tuparí & Mekéns & Akuntsú & Makurap \\
\hline 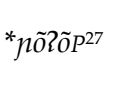 & powder & nõ:P & nõนốP & - & $\begin{array}{c}e-\eta \tilde{o} P \text { 'farofa } \\
\text { flour' }\end{array}$ & - \\
\hline${ }^{*} \eta \tilde{o K}$ & chigoe flea & по̃ K & jõK 'pimple' & - & - & по̃K \\
\hline $\begin{array}{l}{ }^{*} \tilde{e} T \\
{ }^{*} \mu \tilde{e}(:) T\end{array}$ & $\begin{array}{c}\text { faeces, guts } \\
\text { ashes }\end{array}$ & $\begin{array}{c}\eta \tilde{e} T \\
\{k \boldsymbol{u}\} \eta \tilde{e}(:) T\end{array}$ & $\begin{array}{c}n \tilde{e} T \\
\{k \mathcal{u}\} \eta \tilde{e}(:) T\end{array}$ & 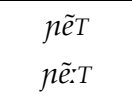 & 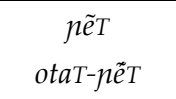 & $\begin{array}{c}\eta \tilde{e} T \\
\{k \tilde{t}\} \hat{\ell} \tilde{e}: T\end{array}$ \\
\hline 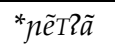 & meat & nẽrã & пёTRã & nẽrã & - & nĩr $\tilde{a}^{28}$ \\
\hline${ }^{*} m \tilde{a} \eta \tilde{\imath}$ & manioc & $m \tilde{a} n \tilde{\imath}$ & $m \tilde{a} c^{29}$ & - & - & mãnn \\
\hline${ }^{*} n \tilde{\imath}: K^{30}$ & smoke & nn:K & $\{s\} \tilde{\imath} K$ & otaT-ñ்:K & $n \tilde{\imath} K$ & 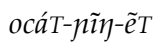 \\
\hline
\end{tabular}

Table 5. Proto-Tuparian */j/ (oral ${ }^{*}$, nasal $\left.{ }^{*} n\right)$

In a subset of relational stems, an unexpected correspondence occurs between Core Tuparian vowel-initial stems and Makurap $c$ - or $n$-initial stems. It is worthy of note that all such stems are, at the very least, disyllabic. We reconstruct their PTpr etyma as */j/-initial and posit a shared innovation for Core Tuparian, which consists in an almost regular loss of stem-initial */j/ at the left margin of polysyllabic relational stems. We have been so far unable to explain

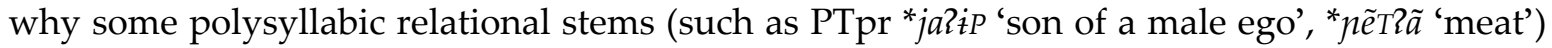
resisted the deletion of $* / \mathrm{j} /$. An anonymous reviewer suggests that the loss of $* / \mathrm{j} /$ should be viewed as a morphological - rather than phonological - change; however, at present we lack evidence for analyzing ${ }^{*} / \mathrm{j} /$ - as a prefix (other than in the relational nouns ${ }^{*} j-e K$ 'house.POss' and *j-ekiP 'arrow.POSS', which are indeed derived from the absolute nouns *eK 'house' and *ekiP 'arrow'). The relevant cognate sets are given in Table 6 below.

$\mathbf{P T p r}^{*} w$. We reconstruct a labiovelar approximant ${ }^{*} w$ for Proto-Tuparian. In Makurap, it is reflected as $\beta$ before oral nuclei and as $m$ before nasal nuclei (Makurap has no $/ \mathrm{w} /$ ). In the Core Tuparian languages, it usually retains its labiovelar articulation (Way $/ \mathrm{n}^{\mathrm{w}} /$, Tup $w$, Mek/Aku $k^{w}$ ) except before rounded vowels, where one finds Way /y/, Tup $\varnothing$, Mek/Aku $k \cdot{ }^{31}$ It is thus possible that Proto-Core Tuparian */w/ had a velar allophone $\left.{ }^{*} \gamma\right]$, which occurred preceding rounded nuclei. In Wayoró and in the Corumbiara languages, both allophones (PCT ${ }^{*}[\mathrm{w}]$ and ${ }^{*}[\gamma]$ ) underwent developments which affected most or all approximants in these languages: in Wayoró, they changed into underlying nasal stops $/ \mathrm{n}^{\mathrm{w}} /$ and $/ \mathrm{h} /$ (which surface as $\left[\mathrm{ng}^{\mathrm{w}}\right]$ and $[\mathrm{ng}]$ in oral environments), whereas in the Corumbiara languages they were

${ }^{27}$ Although no cognate in Makurap is known, PCT * $n \tilde{\imath} \imath \tilde{P} P$ can be securely traced back to PTpr * nõ $2 \tilde{P}$ because a precise external cognate is found in Proto-Mundurukú ( ${ }^{*} \partial \tilde{\sigma} m$ 'powder', cf. Picanço 2005: 181).

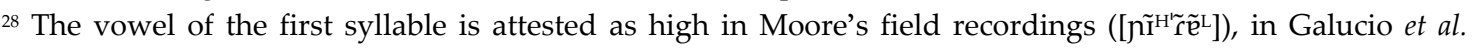

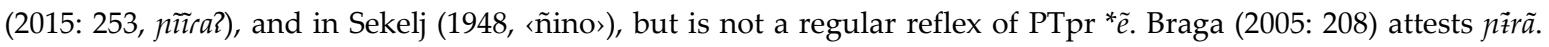
The expected form nẽer is in fact documented in one of our secondary sources (Moore \& Galucio 1994: 133).

${ }^{29}$ This token instantiates the loss of PTpr ${ }^{*} \eta$ in Tuparí preceding an $\tilde{\imath}$ (that way, PTpr/PWT ${ }^{*} m \tilde{a} n \tilde{\imath}>{ }^{*} m \tilde{a} \tilde{\imath}$ ). The hiatus in the resulting form was resolved by reanalyzing [ĩ] as a coda offglide [j], which is the surface realization of the underspecified palatal coda $-C$ in modern Tuparí (cf. Singerman 2016).

${ }^{30}$ The Makurap form is from Moore's field data. The Tuparí form appars to contain the fossilized third person prefix: $s-\tilde{i} K<{ }^{*} j-\tilde{i} K<\mathrm{PCT}{ }^{*} i-n \tilde{\imath} K$; this shows that the sound change ${ }^{*} n \tilde{\imath}>\tilde{\imath}$ preceded the fortition of PCT ${ }^{*} j$ in Tuparí. In the Corumbiara languages, the root-initial is attested as $n$ (instead of the expected * $n$ ) in all sources (Aragon 2008: 53, 2014: 108; Galucio et al. 2015: 259) except Aragon \& Cabral (2005: 1537), who attest the Akuntsú word as otáT-nît, with the expected palatal onset but with an unexpected coronal coda.

31 The Kupndiiriat dialect of Wayoró appears to have $\beta$ as its default reflex, though only one reliable datum is attested, Biri 'açaí' (Nogueira 2019: 4). 


\begin{tabular}{|c|c|c|c|c|c|c|}
\hline \multicolumn{7}{|c|}{ oral } \\
\hline *jai & flour, crumbs & - & håú & - & - & $t \int a \dot{a}$ \\
\hline *ja:mbi & crop seed & $a \beta i$ & a:Psí & a:pi & - & $\underline{c a \tilde{m} b i}$ \\
\hline *jape & sharpened & - & apé & - & apé & mbi-cape \\
\hline *jato & big & - & -ató & atso & $-a t \int o$ & $\underline{\text { cato }}$ \\
\hline *jato & to bathe & ato- & ató- & atso- & atfo- & cato- \\
\hline *jati & $\begin{array}{l}\text { pain, to hurt; } \\
\text { sour }\end{array}$ & ati & así & atsi & $a t \sqrt{i}$ & cáti \\
\hline *jo(2)a & $\begin{array}{c}\text { brother } \\
(\text { female ego) })^{32}\end{array}$ & $o k^{w} a$ & owá orá & $o k^{w} a$ & $o k^{w} a$ & cóa \\
\hline *jopaP & grain & - & opáP 'maize' & opaP 'maize' & - & $\underline{\text { copaP }}$ \\
\hline *jopiza & egg & upia ${ }^{33}$ & opsíza & opitsa & õpíta & cópia \\
\hline *joac & tail & $o k^{w} a c$ & oác & $o k^{w} a c$ & $o k^{w} a ́ c$ & nёт-coac \\
\hline${ }^{*} j e \beta a$ & $\begin{array}{l}\text { forehead } \\
\text { CT only: }\end{array}$ & - & épa 'eye' & - & eba-pé & cépa \\
\hline${ }^{*}$ јеßа-јорар & eye & eßa-paP & - & eba-opaP & eba-páp & - \\
\hline${ }^{*} j e \beta a-p i$ & face & - & épa-Psi & Sio eba-pi & eba-pí & - \\
\hline${ }^{*} j-e-k \dot{i} P$ & arrow.POSS & - & $e-k \mathfrak{u} P$ & - & - & $\underline{c-e-k \dot{k} P}$ \\
\hline${ }^{*} j e i$ & blood & aut & étu & $a \dot{t}^{34}$ & $e ? \dot{t}$ & cét \\
\hline \multicolumn{7}{|c|}{ nasal } \\
\hline *nãpi(-2a) & nose & $\tilde{a} p i-a$ & $\tilde{a} P s i$ & $\tilde{a} p i-t s a$ & apí-ta & näpi \\
\hline *nã $\eta \tilde{a}$ & branch & - & $\tilde{a} k \tilde{a}$ & - & - & hãaga \\
\hline
\end{tabular}

Table 6. Loss of stem-initial Proto-Tuparian */j/ in polysyllabic relational stems

fortitioned to $/ \mathrm{k}^{\mathrm{w}} /$ and $/ \mathrm{k} /$, respectively. Tuparí preserved ${ }^{*}[\mathrm{w}]$ without further changes, whereas the allophone ${ }^{*}[\gamma]$ yielded zero.

Unlike PTpr $* / j /$, PTpr $* / w /$ does not show radically different reflexes in oral and nasal environments. Only in Makurap does one consistently find different phonemes ( $\beta$ vs. $m$ ) as its reflxes. More marginally, the Sakurabiat dialect of Mekéns appears to sometimes have $\eta^{w}$ as the reflex of PTpr ${ }^{*} w$ in nasal environments (e.g. $\eta^{w} \tilde{a} \tilde{e}$ 'pot') as opposed to $k^{w}$, which is found in oral environments in Sakurabiat and in all environments in Guaratira and Siokweriat (cf. Galucio 2001: 19). In our proposal, this is accounted for by positing a voiced stop stage in

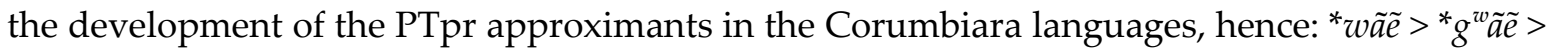
Sak $\eta^{w} \tilde{a} \tilde{e}$, Gua $k^{w} \tilde{a} \tilde{e}$, Sio $k^{w} \tilde{a} 2 \tilde{e}$, Aku $k^{w} \tilde{a} 2 \tilde{e}$.

The Tuparian etymologies which instantiate PTpr ${ }^{*} w$ are listed in Table 7.

This concludes our presentation of the reflexes of the approximant series of ProtoTuparian. In what follows, we present evidence for reconstructing innovative approximants for earlier stages of individual Tuparian languages and the proto-languages of low-level subgroups.

${ }^{32}$ In all Tuparian languages except Akuntsú, the reflexes of this kinship term also denote a woman's cousin (son of a woman's paternal uncle). In addition, Makurap cóac is used for man's and woman's brothers alike (Nogueira et al. 2019: 42).

${ }^{33}$ We have no explanation for the occurrence of $\mathcal{t}$ (as opposed to $o$ ) in this word.

${ }^{34}$ We have no explanation for the occurrence of $a$ (as opposed to $e$ ) in this word. Note the similarity of this (apparently irregular) development to the dissimilation of *ei, *eut to ai, au in Wayoró (Nogueira 2015). 


\begin{tabular}{|c|c|c|c|c|c|c|}
\hline PTpr & gloss & Wayoró & Tuparí & Mekéns & Akuntsú & Makurap \\
\hline \multicolumn{7}{|c|}{ oral } \\
\hline${ }^{*} a w a^{35}$ & yam & $a g^{w} a$ & awa\{té\} & $a k^{w} a$ & $a k^{w} a ́$ & - \\
\hline${ }^{*}$ wara(:) $C^{36}$ & $\begin{array}{l}\text { frog/toad sp. (CT } \\
\text { only) }\end{array}$ & $\eta g^{w} \operatorname{ara}(:) C$ & warác- $2 a$ & $k^{w}$ ara:C & $k^{w}$ arác & - \\
\hline${ }^{*}$ wariza & bat (CT only) & $\eta g^{w}$ aria & wáriza & $k^{w}$ aritsa & - & -37 \\
\hline *waco & alligator & $\eta g^{w} a c c o$ & wáo & $k^{w}$ ato & $k^{w}$ ató & Báto \\
\hline *wako & guan & $\eta g^{w} a k o$ & wakó & $k^{w} a(:) k o$ & $k^{w} a k o ́$ & $\beta a k o ́-p \tilde{e} P$ \\
\hline *wakara ${ }^{38}$ & great egret & - & $\begin{array}{l}\text { wakara-tó } \\
\text { 'jabiru' }\end{array}$ & - & - & Bakara \\
\hline *wawo & sweet potato & $\eta g^{w} a g o^{39}$ & wáo & $k^{w} a(:) k o$ & $k^{w} a k o ́$ & $\beta a \beta o ́$ \\
\hline${ }^{*} w a R i$ & stone & $\eta g^{w} a i$ & wázi & $\begin{array}{c}k^{w} a i \\
\text { Sio } k^{w} a z i\end{array}$ & $k^{w} a z i$ & $\beta a i$ \\
\hline${ }^{*}$ waT-40 & to go away & $\eta g^{w} a T-$ & waT- & $k^{w} a T_{-}$ & $k^{w} a T_{-}$ & ? $\beta a T$ 'always' \\
\hline${ }^{*} w a c ? a$ & labret (CT only) & - & wác?a & - & $k^{w} a c t a$ & - \\
\hline $\begin{array}{c}{ }^{*} w a K- \\
{ }^{*} w a K-t o P-41\end{array}$ & $\begin{array}{l}\text { to cry; sound } \\
\text { to hear }\end{array}$ & $\begin{array}{c}- \\
\eta g^{w} a K-t o-a\end{array}$ & $\begin{array}{c}w a K^{-} \\
-\end{array}$ & $\begin{array}{c}k^{w} a K \\
k^{w} a K-t s O P-\end{array}$ & $\begin{array}{c}k^{w} a K \\
k^{w} a K-t \int o P-\end{array}$ & $\begin{array}{c}- \\
\beta a T-t o-a \text { 'to look' }\end{array}$ \\
\hline
\end{tabular}

Table 7. Proto-Tuparian */w/ (oral and nasal *w) (to be continued)

${ }^{35}$ Although no cognate in Makurap is known, PCT *awa can be securely traced back to PTpr *awa because a precise external cognate is found in the Juruna branch (Yudjá awa[2á] 'yam', Mondini 2014: 113). The expected reflex in Wayoró would be * $\tilde{a} \eta g^{w} a$; it is unclear why the medial consonant is oral.

${ }^{36}$ The vowel length is attested in the Wayoró and Mekéns reflexes by Galucio et al. (2015: 273). The Wayoró form is given with a short vowel in Nogueira $(2011: 43,52)$.

${ }^{37}$ The Makurap term for 'bat' is Bacáriac. Despite the obvious similarity to the Core Tuparian forms, there is no regular correspondence between them; Mak ßacáriac could go back to PTpr *wajari(2)ac. It is unclear whether we are dealing here with an irregular development or with an indirect borrowing.

38 This token is a Wanderwort, as similar forms are found in many unrelated languages spoken all across the Amazon and even as far away as on the Caribbean coast of South America. Epps (2020, entry 'great egret') lists multiple languages of the Cariban (Carijona, E’ñepa, Wayana, Yabarana), Guahiboan (Cuiva, Sikuani, Macaguán), Arawakan (Paresí), Sáliban (Piaroa, Sáliba), Nadahup (Nadëb), and Tupí-Guaraní (Kokama, Wajãpí) families and groups as having a Wanderwort of the approximate shape \%wakara meaning 'great egret'. One may add other Arawakan (Wapixana wakara, Mehinaku wakala, Proto-Ta-Arawakan *wak'ara; Silva et al. 2013: 106, Corbera Mori 2008: 64; Nikulin \& Muzykantova in prep.) as well as Tupian (Suruí-Paiter wakár, Zoró wakal, Ka'apor wakara; Bontkes 1978: 18, Lacerda 2014: 321, Caldas 2009: 304) languages to this list. Given the regularity of the correspondence between the Tuparí and Makurap forms, we deem it possible that *wakara was borrowed from an unknown source into Proto-Tuparian.

${ }^{39}$ The expected reflex of PTpr ${ }^{*} w$ before $o$ would be ${ }^{*} g$, not $g$. It is likely that that some sort of a dissimilation of the kind *NDVND... > NDVD... applied in this word, as in *ndando > ndato 'armadillo'. In fact, Nogueira (2019: 8 , with a reference to her ongoing research) entertains the hypothesis that Wayoró $[\mathrm{g}]$ and $\left[\mathrm{g}^{\mathrm{w}}\right]$ could be even synchronically described as allophones of $/ \mathrm{h} /$ and $/ \mathrm{y}^{\mathrm{w}} /$.

${ }^{40}$ Even if Makurap $\beta a T$ 'always' does not belong to this cognate set, the Core Tuparian verb cannot be regarded as a Core Tuparian innovation because precise external cognates are found across Tupian (Karitiana hot, Sateré-Mawé waT 'to go.PL').

${ }^{41}$ This compound can be analyzed as 'sound-see'. The development ${ }^{*}-K t->-T t$ - in Makurap is unparalleled. The Wayoró and Makurap reflexes are attested only in their forms which contain the thematic vowel $-a-$, which triggers the deletion of the stem-final consonant. Clear cognates of PTpr *waK are found in other Tupian languages as well (e.g. Karitiana hok 'to play violin', Sateré-Mawé waK 'to cry’). 


\begin{tabular}{|c|c|c|c|c|c|c|}
\hline PTpr & gloss & Wayoró & Tuparí & Mekéns & Akuntsú & Makurap \\
\hline${ }^{*} w \dot{i}^{42}$ & blow & - & - & - & - & $\beta \dot{i}$ \\
\hline * ãw & $\begin{array}{l}\text { to enter } \\
\text { (WT only) }\end{array}$ & $\tilde{a} \eta g u_{-}$ & $\tilde{a} \mathfrak{u}^{-}$ & - & - & - \\
\hline${ }^{*} w o(:)^{43}$ & thorn & $\eta g o:$ & - & $k o^{44}$ & $\begin{array}{l}\text { ko 'fish- } \\
\text { hook' }\end{array}$ & - \\
\hline${ }^{*} a(:) w o$ & bone & - & - & $a: k o$ & - & $a o^{45}$ \\
\hline *wora & $\begin{array}{c}\text { sound, speech } \\
\text { (?) }\end{array}$ & ygora 'music' & - & - & - & $\begin{array}{l}\text { Borá-pi } \\
\text { 'mouth' }\end{array}$ \\
\hline *woroa- & $\begin{array}{l}\text { to look for } \\
\text { (CT only) }\end{array}$ & ygora- & óroa- & kora- & kóra- & - \\
\hline *aworo ${ }^{46}$ & parrot & - & áwro áoro & - & - & - \\
\hline${ }^{*} w o P$ & red & $\eta g O P$ & $O P$ & koP & koP & $\beta O P$ \\
\hline${ }^{*} w o T-k \dot{t} P$ & neck & $\eta g O T-k \mathfrak{H P}$ & $O T-k \mathfrak{u} P$ & $\begin{array}{c}\text { kOT-kiP } \\
\text { Sio kitT-kìP }\end{array}$ & $p \dot{i} T-k \hat{t} P^{47}$ & BóT-kìP \\
\hline *wetoK & far & $\eta g^{w}$ etoK & ? toK & $k^{w}$ etsoK & - & BétoK \\
\hline *werep & $\begin{array}{l}\text { foreigner } \\
\text { (CT only) }\end{array}$ & $\eta g^{w}$ ereP & - & $k^{w}$ ereP & $\begin{array}{l}\text { 'deréP } \\
\text { 'dark' }\end{array}$ & - \\
\hline${ }^{*}$ wejaP & $\begin{array}{l}\text { anteater } \\
\text { (CT only) }\end{array}$ & $\eta^{w} \tilde{e} n d a P$ & - & $k^{w} e t a P$ & $k^{w}$ itáa $P^{48}$ & - \\
\hline$*_{w e P-49}$ & to go up & $\eta g^{w} e P-$ & - & $k^{w} e P-$ & $k^{w} e P-$ & - \\
\hline${ }^{*} w i$ & $\mathrm{ax}$ & - & wi(:) & $k^{w i} i$ & $k^{w_{i}}$ & $\beta i$ \\
\hline *ara:wi & $\begin{array}{l}\text { peanut } \\
\text { (CT only) }\end{array}$ & $\operatorname{ara}^{2}{ }^{w} i$ & - & $\operatorname{ara}(:) k^{w} i$ & $\operatorname{arak}^{w} i$ & -50 \\
\hline
\end{tabular}

Table 7. Proto-Tuparian */w/ (oral and nasal *w) (to be continued)

${ }^{42}$ Although no cognate in Core Tuparian is attested in our primary sources, Mak $\beta \dot{t}$ can be securely traced back to PTpr *wi because precise external cognates are found across Tupian (e.g. Karitiana he: 'to blow'). A likely cognate in Tuparí, $\mathfrak{z}$ - 'to blow, to play a wind instrument' is mentioned by Rodrigues (2002: 291), but we were unable to locate this form in our primary sources on Tuparí, thus putting its existence in doubt.

${ }^{43}$ Although no cognate in Makurap is known, PCT *wo(:) can be securely traced back to PTpr *wo(:) because precise external cognates are found across Tupian (Karitiana $h \dot{t}$ 'thorny tree', Sateré-Mawé $h u$, PTG *ju 'thorn').

${ }^{44}$ Attested by Wanda Hanke only (Hanke et al. 1958: 212) as 〈kú〉 'thorn, needle'.

${ }^{45}$ The absence of $\beta$ is unclear. The word is frequently attested as cé $\beta$-ao ([ce ${ }^{\mathrm{H}}$. $\left.\beta \mathrm{ao}: \mathrm{R}^{\mathrm{L}}\right]$ in Moore’s data; cf. also Braga 2005: 162), with the relationalizer prefix ceP- (Braga 2005: 42-3).

46 Tup áwro áoro can be securely traced back to PTpr *aworo because precise external cognates are found across Tupian (Proto-Mundurukú *áro, PTG *ajuru).

${ }^{47}$ The development of PCT ${ }^{*} w o$ into Akuntsú $p \dot{t}$ is not known to be regular. Note that the unrounding of ${ }^{*} O$ is also attested in Siokweriat.

48 The development of PCT * $e$ into Akuntsú $i$ is not known to be regular. The word is attested as [wi'tap'] [wi'ttap'] [wi'tdap'] in Aragon (2008: 57), but is phonologized here with a $/ \mathrm{k}^{\mathrm{w}} /$ because this is almost certainly the same word as the one found in the hydronym $K^{w i t a P} k i$ (Aragon 2014: 14), plausibly interpretable as 'anteater river'; the optional realization of $/ \mathrm{k}^{\mathrm{w}} /$ as [w] is independently attested by Aragon (2014: 57sqq.).

49 Although no cognate in Makurap is known, PCT *weP can be securely traced back to PTpr *weP because precise external cognates are found across Tupian (Karitiana hap 'to rise (of sun)', Awetí teP 'to go up'; Landin 2005: 10, Reiter 2011: 205).

50 The Makurap term for 'peanut' is attested as araßoik (Braga 2005) or aráßi:K (Moore’s data). Despite the obvious similarity to the Core Tuparian forms, there is no regular correspondence between them. It is unclear whether we are dealing here with an irregular development or with an indirect borrowing. 


\begin{tabular}{|c|c|c|c|c|c|c|}
\hline PTpr & gloss & Wayoró & Tuparí & Mekéns & Akuntsú & Makurap \\
\hline${ }^{*} e w i T^{51}$ & honey, bee & $\tilde{e} \eta g^{w} i T$ & ewíT & $\begin{array}{c}e k^{w} i r-i t s a \text { 'bee sp.' } \\
\text { Sio } e k^{w} i T\end{array}$ & $e k^{w} i T$ & - \\
\hline *wiT?i & açaí & $\begin{array}{l}\text { Ngw } \eta g^{w i r i} \\
\text { Kup Biri }\end{array}$ & wíTRi & $k^{w} i r i$ & $k^{w i} i i^{\prime}$ & Birí\{ca\} \\
\hline \multicolumn{7}{|c|}{ nasal } \\
\hline *wãmõ $\tilde{a}$ & shaman & - & wấmõ $2 \tilde{a}$ & $k^{w} \tilde{a} m \tilde{a} \tilde{a}$ & $k^{w} \tilde{a} m \tilde{o} \tilde{a}$ & $\underline{m a \tilde{a} \tilde{a} \tilde{a}}$ \\
\hline${ }^{*} w \tilde{a} k \tilde{z} \eta \tilde{a}^{52}$ & agouti & $\eta^{w} \tilde{a} k \tilde{u} \eta \tilde{a}$ & - & 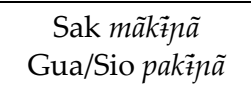 & pakẫnã & $m \tilde{a} k \tilde{t} h \tilde{a}$ \\
\hline${ }^{*} w \tilde{a} \tilde{e}^{53}$ & pot & $\eta^{w} \tilde{a} \tilde{e}$ & $w \tilde{a} \tilde{e}$-tóp-?a & $\begin{array}{l}\text { Sak } \eta^{w} \tilde{a} \tilde{e} \\
\text { Gua } k^{w} \tilde{a} \tilde{e} \\
\text { Sio } k^{w} a 2 \tilde{e}\end{array}$ & $k^{w} \tilde{a} R \tilde{e}$ & - \\
\hline${ }^{*} w \tilde{a} c k \dot{t} T$ & $\begin{array}{c}\text { plate } \\
\text { (WT only) }\end{array}$ & $\eta^{w} \tilde{a} c k \mathfrak{H} T$ & wãckút & - & - & - \\
\hline${ }^{*} w \tilde{z}-$ & to enter & $\eta \tilde{\mathcal{H}}-$ & - & - & - & $m \tilde{\mathfrak{t}}^{-}$ \\
\hline *wõ & pet (CT only) & $\eta \tilde{O}$ & ? õ[åkiT] & $\eta \tilde{O}$ & - & - \\
\hline *wĩRĩK & leafcutter ant & $\eta^{w_{i K}}$ & wîñ & - & - & $m \tilde{i} K$ \\
\hline
\end{tabular}

Table 7. Proto-Tuparian */w/ (oral and nasal *w)

\subsection{Loss of syllabicity in high vowels}

This subsection deals with the sound change whereby the high vowels $* / \mathrm{i}$ o/ (and possibly their nasal equivalents) of PTpr became approximants when adjacent to vowels. Note that in the phonological systems of all Tuparian languages /o/ is analyzed as a high vowel, as there is no $/ \mathrm{u} /$. This type of sound change arguably recurred multiple times in the histories of the Tuparian languages, which is quite unsurprising given its naturalness. Its operation is most easily seen in the allomorphy patterns of the 3NCRF prefix ( $\mathrm{PTpr}{ }^{*} i$ ) and of the 1sG prefix (PTpr ${ }^{*} O_{-}$).

PTpr $* / \mathrm{i} /$ and $* / \mathrm{o} /$ were not affected by this process in the same fashion in the individual languages: while only Wayoró and Tuparí show traces of the desyllabification of the reflexes of $\mathrm{PTpr} * \mathrm{o} /$, the front high vowel $* / \mathrm{i} /$ has been affected in all daughter languages. In Makurap, the PTpr 3NCRF prefix */i-/ before vowels yielded /n-/ (which surfaces as $n d z$ - in oral environments and as $n$ - in nasal environments), as shown in 1. Phonetically, this development must have proceeded through the stage ${ }^{*} j$ (hence, $\left.\mathrm{PTpr}{ }^{*} i V->{ }^{*} j V->* / n V-/\right)$ and evidently postdates the specifically Makurap sound change ${ }^{*} j>c$.

MAKURAP: /n-/ ndz- oral, $n$ - nasal (Braga 2005: 50, 204; the glosses are ours)
a. ndz-akáre-T
/n-akare-eT/
b. $\quad$ ndz-apiter-eT
3NCRF-head-POSS
/n-apiteT-eT/
'his/her head'
3NCRF-sadness-POSS
'his/her sadness'

51 Although no cognate in Makurap is known, PCT *ewiT can be securely traced back to PTpr *ewiT because precise external cognates are found all across Tupian: Karitiana e:t (<*ahit), Proto-Mundurukú *eit, Sateré-Mawé ewiti, Awetí ekit, PTG *iT.

52 The reflexes of this word in the Corumbiara languages show labial consonants (Sak $m, \mathrm{Gua} / \mathrm{Sio} / \mathrm{Aku} p$ ) instead of the expected labiovelars (Sak $\eta^{w}$, Sua/Sio/Aku $k^{w}$ ). That is, Proto-Corumbiara innovated by replacing ${ }^{*} g^{w} \tilde{a} k \tilde{z} \eta \tilde{a}$ with *bãkz̃ $n \tilde{a}$. Currently we have no explanation for this (apparently idiosyncratic) development.

${ }^{53}$ Although no cognate in Makurap is known (unless $\tilde{i} \tilde{e}$ 'pot' is related), PCT *wãe can be securely traced back

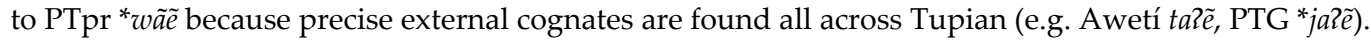




\section{c. $\quad \underline{\text { etetenã }} \underline{\underline{k i t e}} \underline{\underline{p e}} \underline{\boldsymbol{n}-\tilde{o}-\tilde{a}} \quad \underline{\beta i T}$ \\ letetenã kite pe n-õP-a $\quad \underline{\beta i T /}$ \\ after_that people LOC 3NCRF-give-TH all \\ 'After that, he gave it to everyone.'}

In the Core Tuparian languages, the PTpr 3NCRF prefix */i-/ was desyllabified before vowels as well, yielding PCT $* / j /$. This must have happened after PTpr ${ }^{*} j$ became PCT ${ }^{*}$, because the reflexes of PCT ${ }^{*} \delta$ and ${ }^{*} j$ in oral environments are distinct in all Core Tuparian languages except Akuntsú (PCT ${ }^{*} \delta>$ Way $n d$, Tup $h-/-\varnothing$, Mek $t$, Aku $t$, whereas PCT ${ }^{*} j>$ Way $n d z$, Tup $s$, Mek ts, Aku t). In nasal environments, however, there is no distinction between the reflexes of PTpr */j/ and those of PTpr */i/ before vowels in PCT, as both merge in PCT ${ }^{*} \mu .54$ That way, we believe that the inventory of approximants was augmented by one phoneme in PCT as compared to PTpr: first, PTpr ${ }^{*} j$ was dentalized to PCT ${ }^{*}$, leaving room for PTpr ${ }^{*} i>\mathrm{PCT}^{*} j$ (before vowels). In $2-5$, we show the prevocalic allomorphs of the 3NCRF prefix in each Core Tuparian language.

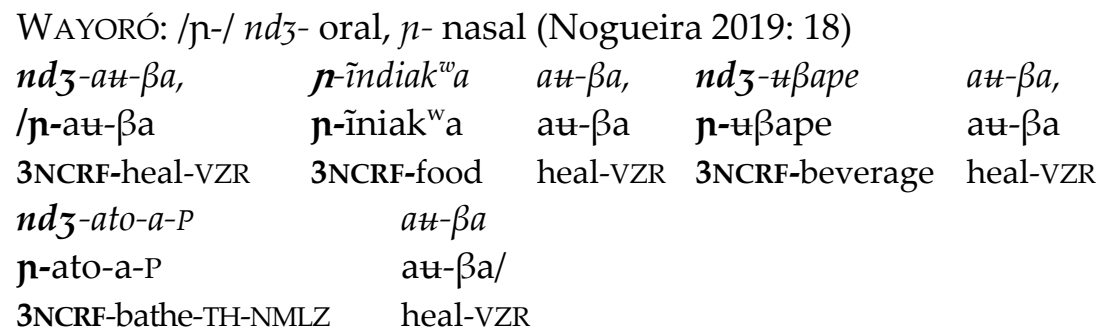

'He is healing it, healing her food, healing her drink, healing her bath.'

TUPARÍ: $s$ - oral, $n$ - nasal (Singerman 2018: 60-2) ${ }^{55}$
a. s-opé
b. $s-a T$
c. $\quad$ - $-\tilde{o} p e ́$
d. $\boldsymbol{n}$-õpó
3NCRF-thigh
3NCRF-grab
3NCRF-tongue
3NCRF-kill
'his/her thigh'
'to grab him/her/it'
'his/her tongue'
'to kill him/her/it'

MEKÉNS: ts- oral and nasal (Galucio 2001: 35-7, 191)
a. ts-akoP
b. ts-an $\tilde{t} P$
c. $t s-\tilde{o}-k^{w} e-a-T$
/ts-akoP
ts-anĩP
ts-(m) $\tilde{\mathrm{o}}-\mathrm{k}^{\mathrm{w}} \mathrm{eP}-\mathrm{a}-\mathrm{T} /$
3NCRF-be_hot
3NCRF-head
'hot (it)'
'his/her/its head'
3NCRF-CAUS-climb-TH-PST

d. ãrãmĩrã, aotse ts-õpo ka:T i-tser-a-T

/ãrãmĩrã aotse ts-õpo ka:T i-tseT-a-T/

woman man 3NCRF-beat and 3NCRF-leave-TH-PST

'The woman, the man beat her and she left.'

\footnotetext{
${ }^{54}$ One could claim that Mekéns has no merger: PTpr/PCT ${ }^{*} n$ yields $n$ in Mekéns, whereas the allomorph of the 3NCRF prefix which occurs before nasal vowels is ts- (Galucio 2001: 35, fn. 6; 225, fn. 24) and not * $n$. We believe that in Mekéns the allomorph s-, originally restricted to stems which start with oral vowels, has been analogically extended to all vowel-initial stems. That way, Mekéns forms such as ts-õpo 'to beat him/her/it' (4d) are probably not cognate with Akuntsú n-õp-a (5d) or Tuparí n-õpo (3d), but rather arose through analogy.

${ }_{55}$ At different occasions, Singerman (2018) analyzes $\mu$ - as a realization of $/ \mathrm{i}-/$ (p. 60-2) or of /j-/ (p. 371). For our current purposes, the choice between these two analytical options is irrelevant. Also note that in Tuparí the allomorph $i$-, which was historically restricted to consonant-initial stems, may synchronically occur before vowels, as in i-eT 'his/her name' (Singerman 2018: 56), as a result of the elision of PCT ${ }^{*} \partial\left({ }^{*} i\right.$-ðеT).
} 
AKUNTSÚ: $t$ - oral, $n$ - nasal (Aragon 2014: 46, 138, 177, 279) ${ }^{56}$
a. $t$-akoP te
3NCRF-be_hot FOC
'It is hot.'
b. tatfo, tatfe tiri $t$-ajtfi
Tatjo Tate two 3NCRF-wife
'Tat $\int 0$ and Tatfe were his two wives.'
c. t-anãp etfe kaP
3NCRF-head DIFF wasp
'A wasp is on his head.'
3NCRF-beat-TH
'to beat him'
d. $\boldsymbol{n}-\tilde{o} p-a$

In some Core Tuparian languages, the innovative PCT ${ }^{*} j$ has merged with segments whose ultimate source is different from ${ }^{*} i$. In subsection 3.4, we will show that Proto-Corumbiara innovated by creating transitional glides (as in PCT *piza > Proto-Corumbiara *pija), which have the same reflexes as PCT ${ }^{*} j<$ PTpr ${ }^{*} i$ (that is, Mekéns ts, Akuntsú $t$ ). Similarly, the word for 'spider monkey' can be reconstructed as Proto-Corumbiara *jakiraP (> Mekéns tsakiraP, Akuntsú takírap).

Now we turn to the desyllabification of $\operatorname{PTpr}{ }^{*} 0$. This process is synchronically attested in Tuparí, in which the 1SG prefix occurs as o- before consonants, but as $w$ - before vowels (Singerman 2018: 42); it also coalesces with a following /o/ or /õ/, yielding a long vowel. In Wayoró, the 1SG prefix also occurs as o- before consonants; before unrounded vowels, however, one finds the allomorph $/ \mathrm{m}-/$ ( $m b$ - in oral environments, $m$ - in nasal environments), whereas before rounded vowels the zero allomorph occurs (Nogueira 2019: 11, 15, 150-1). This is shown in Table 8.

\begin{tabular}{|c|c|c|c|c|}
\hline & \multicolumn{2}{|c|}{ Wayoró (Nogueira 2019) } & \multicolumn{2}{|r|}{ Tuparí (Singerman 2018) } \\
\hline before a consonant & $o-/ \mathrm{o}-/$ & 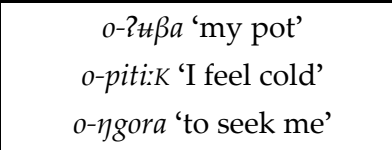 & $o-$ & $\begin{array}{c}o-s i \text { 'my mother' } \\
o-k \tilde{e} P k-a: \text { 'I nursed' } \\
o \text {-karãp 'toward me' }\end{array}$ \\
\hline $\begin{array}{l}\text { before a rounded } \\
\text { vowel }\end{array}$ & $\phi-1 \phi-1$ & $\begin{array}{l}\varnothing \text {-upipe 'my port' } \\
\text { Ø-õmb-a: 'hit me!' }\end{array}$ & $O-O \ldots \rightarrow O O^{-}$ & $\begin{array}{c}o: P(O+O P) \text { 'my father' } \\
\text { o:jaora }(o+\tilde{o} j a o T+a) \text { 'to answer me' }\end{array}$ \\
\hline $\begin{array}{l}\text { before an oral un- } \\
\text { rounded vowel }\end{array}$ & $m b-/ \mathrm{m}-/$ & $\begin{array}{c}m b \text {-apiteP 'my ear' } \\
m b-a t o-a-P \text { 'my bath' } \\
m b-e-t f \mathfrak{t}: P-k^{w} a-T \text { 'I got wet' }\end{array}$ & $w-$ & $\begin{array}{c}w \text {-apap?a 'my head' } \\
w \text {-e-kiarap-k-a 'I became happy' } \\
w-e-p a k-a \text { 'I woke up' }\end{array}$ \\
\hline $\begin{array}{l}\text { before a nasal un- } \\
\text { rounded vowel }\end{array}$ & $m-/ \mathrm{m}-/$ & 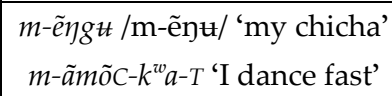 & & $\begin{array}{l}w \text {-ẽkẽ } \sim 2 \tilde{e} k \tilde{e} T-k-a P \\
\text { 'my throwing up' }\end{array}$ \\
\hline
\end{tabular}

Table 8. The allomorphy of the 1SG prefix in Wayoró and Tupari

While the allomorphy pattern attested in Tuparí can be explained away as a consequence of a recent natural sound change $\left({ }^{*} o>w_{-} \mathrm{V}_{\text {[-rounded] }]}\right)$, the pattern found in Wayoró requires a more elaborate diachronic account: positing a one-step sound change such as $* / \mathrm{o} />/ \mathrm{m} /$ would be an entirely implausible solution on typological grounds. Fortunately, there is independent comparative evidence which shows that at some point in the history of Wayoró all inherited word-initial (and some word-medial) approximants have become homorganic (underlying) nasals. We have already seen in 3.1 that PTpr ${ }^{*} j$ and ${ }^{*} w\left(>\mathrm{PCT}{ }^{*}{ }^{*},{ }^{*} w /{ }^{*}[\gamma]\right)$ are reflected in Wayoró as $n d, \eta g^{w} / \eta^{w}$, and $\eta g / \eta$ (underlying $/ \mathrm{n} /, / \mathrm{n}^{\mathrm{w}} /$, and $/ \mathrm{n} /$ ); earlier in this subsection, it has been shown that the innovative PCT ${ }^{*} j$ has yielded Wayoró $n d z / n /$. That way, it appears quite

${ }^{56}$ Aragon (2014: 46, fn. 28) analyzes $n$ - as an allophone of /i-/ but is explicit regarding its phonetic realization. For example, the example 5d is transcribed as [jũ.'ba] [nũ.'ba] in Aragon (2014: 46). 
plausible that the allomorph /m-/ 1SG in Wayoró also continues an earlier approximant, which we reconstruct as pre-Wayoró ${ }^{*} \beta$ - and derive from $\mathrm{PTpr} / \mathrm{PCT}{ }^{*} 0$ - in the prevocalic position. Therefore, forms such as ${ }^{*} \beta$-apite $P$ 'my ear' and ${ }^{*} \beta$-ato- $a-P$ 'my bath' are posited for the preWayoró stage. Later on, ${ }^{*} \beta$ - would have undergone nasalization word-initially (in the intervocalic position, as we have seen in 3.1, it was preserved, as in PCT *eßa-opaP > Wayoró eßa-paP 'eye').

Note that the desyllabification of ${ }^{*} O$ - before vowels cannot be considered an innovation shared by Wayoró and Tuparí, even though it occurred in both languages in comparable contexts. First of all, the outcome of this process is different in pre-Wayoró $\left({ }^{*} \beta-\right)$ and Tuparí (w-). The second piece of evidence for positing two independent innovations is that the allomorph $w$ - in Tuparí occurs not only in originally vowel-initial stems, but also in stems which have diachronically lost their initial consonant (PCT * ${ }^{*}$, preserved as $n d$ in Wayoró). For example, the consonantal allomorph occurs in Tuparí w-eK 'my house' (Singerman 2018: 43), which goes back to PCT ${ }^{*} O$-ðeK (apparently by the way of pre-Tuparí *o-eK). Its Wayoró cognate $o$-ndeK 'my house' (Nogueira 2019: 145, 165), which has not been affected by any process of consonantal loss, expectedly shows the vocalic allomorph $o^{-}$.

The allomorphy patterns examined in this subsection are decisive in establishing the directionality of the sound changes which underlie the correspondence sets involving Wayoró nasal stops and non-nasal segments in other Tuparian languages. If one were to derive them from something other than approximants, it would be quite difficult to explain why Wayoró has $/ \mathrm{m}-/$ and $/ \mathrm{n}-/$ as the prevocalic allomorphs of /o-/ and /i-/, respectively. In our account, this is unproblematically attributed to a combination of two processes: the desyllabification of high vowels in the environment \#_V $\left(^{*} i>{ }^{*} j\right.$ in PCT, ${ }^{*} O>{ }^{*} \beta$ in pre-Wayoró) and the nasalization of approximants in Wayoró $\left({ }^{*} \beta-,{ }^{*}{ }^{*},{ }^{*} j_{-},{ }^{*} w,{ }^{*}[\gamma]>/ \mathrm{m}-/, / \mathrm{n} /, / \mathrm{n}-/, / \mathrm{y}^{\mathrm{w}} /, / \mathrm{y} /\right)$.

\subsection{Proto-Tuparian postoralized nasals and their development in Wayoró}

It is possible to reconstruct three phonemic nasals for Proto-Tuparian: ${ }^{*} / \mathrm{m} /,{ }^{*} / \mathrm{n} /$, and $* / \mathrm{n} /$. In oral environments, they likely acquired an oral phase before an oral nucleus and thus surfaced as ${ }^{*} m b,{ }^{*} n d,{ }^{*} \eta g$ (Galucio \& Nogueira 2012). In nasal environments, $* / m /$ and */n/ appear to have surfaced as ${ }^{*} m$ and ${ }^{*} n$, which have been preserved as such in all contemporary Tuparian languages (in contrast, ${ }^{*} / \mathrm{y} /$ was likely postoralized even before nasal nuclei). Wetzels \& Nevins (2018) classify the allophonic pattern of this type, which is known from many Amazonian languages, as nasal shielding. We call the allophones ${ }^{*} m b,{ }^{*} n d,{ }^{*} \eta g$ postoralized in what follows. For our current purposes, it is essential that the Wayoró reflexes of the postoralized allophones are identical or similar to those of the Proto-Tuparian approximants in oral environments. More specifically,

- $\operatorname{PTpr}{ }^{*} \beta$ and ${ }^{*} m b$ merge in Wayoró as $m b$ - (word-initially) or - $\beta$ - (between vowels);

- $\mathrm{PTpr}^{*} j\left(>\mathrm{PCT}^{*}\right)$ ) and ${ }^{*} n d$ merge in Wayoró as $n d$;

- $\operatorname{PTpr}^{*} w$ before rounded vowels (> PCT $\left.{ }^{*}[\gamma]\right)$ and ${ }^{*} \eta g$ merge in Wayoró as $\eta g$.

Based on the contemporary Wayoró reflexes, one may be tempted to attribute these mergers to a single sound change from the Proto-(Core) Tuparian approximants to Wayoró underlying nasals. Indeed, in 3.1-2 we have seen that most approximants of Proto-Core Tuparian became homorganic nasals in Wayoró: PTpr ${ }^{*} j>\mathrm{PCT}{ }^{*} \delta>$ Wayoró $n d$; $\mathrm{PTpr}{ }^{*} w>\mathrm{PCT}{ }^{*} w{ }^{*}[\gamma]>$ Wayoró $\eta(g)^{w} / \eta(g)$; PTpr ${ }^{*} 0_{-},{ }^{*} i$ - before vowels $>\mathrm{PTpr}^{*} \beta-,{ }^{*} j_{-}>$Wayoró $m(b)-, n d 3^{-}$. In contrast, the Wayoró reflexes of PTpr ${ }^{*} m b,{ }^{*} n d$, and ${ }^{*} \eta g$ are identical to their reconstructed states, as in PTpr ${ }^{*} m b o$ 'hand', *ndeT- 'to grind', * $\eta g a P$ 'wasp' > Wayoró mbo, ndeT-, ygaP. At first glance, these sounds would appear to have been preserved intact in Wayoró all the way from Proto-Tuparian. 
In this paper, however, we advance an alternative proposal. Namely, we hypothesize that the postoralized allophones of PTpr nasals (i.e., * $m b$, * $n d,{ }^{*} \eta g$ ) have been affected by a series of sound changes in Wayoró, which came full cycle to the initial state. The suggested evolution pathway of PTpr ${ }^{*} m b,{ }^{*} n d,{ }^{*} \eta g$ in the Core Tuparian languages is as follows: (i) in PCT, they lose the nasal phrase and become ${ }^{*} b,{ }^{*} d,{ }^{*} g$; (ii) in the Corumbiara languages and in Tuparí, they merge with PCT ${ }^{*} p,{ }^{*} t,{ }^{*} k$ and yield Mek/Aku $p, t s / t \int, k$, Tup $p$ (s-/-Ps- before $i$ ), $t$ (s before $\mathcal{t} / i$ ), $k$; (iii) in pre-Wayoró, they lenite to ${ }^{*} \beta,{ }^{*} \delta,{ }^{*} \gamma$ (and merge, therefore, with PCT * $\beta,{ }^{*} \delta,{ }^{*}[\gamma]$ from $\operatorname{PTpr}{ }^{*} \beta,{ }^{*} j,{ }^{*} w$; the bilabial approximant in pre-Wayoró may also come from ${ }^{*} 0$ - as seen in 3.2); (iv) in contemporary Wayoró, they have been affected by the independently established nasalization process $\left({ }^{*} \beta-,{ }^{*} \delta,{ }^{*} \gamma>/ \mathrm{m} /, / \mathrm{n} /, / \mathrm{n} /\right)$. That way, the development from PTpr ${ }^{*} m b,{ }^{*} n d$, and ${ }^{*} \eta g$ to Wayoró $m b, n d$, and $\eta g$ is assumed to have proceeded in three steps $\left({ }^{*} m b /{ }^{*} n d /{ }^{*} \eta g>\right.$ $\left.{ }^{*} b /{ }^{*} d /^{*} g>{ }^{*} \beta /{ }^{*} \delta /{ }^{*} \gamma>m b / n d / \eta g\right)$, as opposed to a straightforward retention. It also entails that PTpr postoralized nasals and approximants first merged as pre-Wayoró approximants (and not as modern Wayoró underlying nasals).

Crucial evidence for our proposal comes from the development of PTpr ${ }^{*} m b$ after an oral vowel in Wayoró: in this position, it is reflected as $\beta$. Nogueira (2011: 45-6) documents forms such as $o-\beta o$ 'my hand' and $o-\beta i$ 'my foot' (< PTpr $\left.{ }^{*} o-m b o,{ }^{*} o-m b i\right)$, of which the uninflected forms are $m b o$ and $m b i$, respectively (Moore \& Galucio 1994: 133). Note that the environment which conditions the development of PTpr ${ }^{*} m b$ in Wayoró is precisely the same that the one we have seen above for pre-Wayoró ${ }^{*} \beta$ from other sources (PTpr ${ }^{*} \beta$ or ${ }^{*} 0$ ): it is reflected as $/ \mathrm{m} /$ word-initially (as in PCT ${ }^{*} 0$-apiteP $>{ }^{*} \beta$-apiteP $>m b$-apiteP 'my ear'), but is retained as $/ \beta /$ after an oral vowel (as in PCT ${ }^{*} e \beta a-o p a P>e \beta a-p a P$ 'eye'). It is, therefore, conceivable that PTpr * $m b$ (as in * $m b o$ 'hand' and * $m b i$ 'foot') merged with other segments as pre-Wayoró * $\beta$ (as in * $\beta o$ 'hand', ${ }^{*} \beta i$ 'foot', ${ }^{*} 0-\beta o$ 'my hand', ${ }^{*} 0-\beta i$ 'my foot'), which was subsequently reverted to $/ \mathrm{m} /$ wordinitially (and after a nasal vowel) by means of an independently reconstructed process (see 3.2), as in $m b o$ 'hand' and $m b i$ 'foot', but suffered no further changes after an oral vowel, as in $o-\beta o$ 'my hand' and $o-\beta i$ 'my foot'. For PCT, we reconstruct ${ }^{*} b$ based on the fact that neither pre-Wayoró nor Tuparí or Corumbiara show any traces of a nasal phase.

We find it likely that PTpr ${ }^{*} n d$ and ${ }^{*} \eta g$ have undergone in Wayoró a cycle of sound changes comparable to the one described for PTpr ${ }^{*} m b$ in the preceding paragraph. For PCT, we reconstruct ${ }^{*} d$ and ${ }^{*} g$ : in Tuparí and in both Corumbiara languages they merge with PCT ${ }^{*} t$ and ${ }^{*} k$ (thus paralleling the merger of PCT ${ }^{*} b$ and ${ }^{*} p$ in these languages), whereas in Wayoró they merge with PCT ${ }^{*} \partial$ and $*[\gamma]$ as pre-Wayoró ${ }^{*} \delta,{ }^{*} \gamma>$ Wayoró $/ \mathrm{n} /, / \mathrm{n} /$ (thus paralleling the merger of PCT ${ }^{*} b$ and ${ }^{*} \beta$ ) in Wayoró. That way, PTpr *ndeT- 'to grind', " $\eta g a P$ 'wasp' are hy-

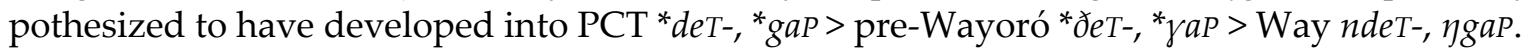

PTpr ${ }^{*} / \mathrm{m} /$. In nasal environments, $\mathrm{PTpr}{ }^{*} / \mathrm{m} /$ surfaced as ${ }^{*} m$ and was preserved as such in all daughter languages. In oral environments, it likely had the allophone * $m b$, which was preserved in Makurap but suffered some changes in the Core Tuparian languages. As stated above, we believe it yielded PCT ${ }^{*} b$. In Tuparí and in the Corumbiara languages, it merged with the reflexes of PTpr/PCT ${ }^{*} p$ as Tuparí $p$ (assibilated to $s-/-P S$ - before $i$ ) and Mekéns/Akuntsú $p$. In pre-Wayoró, PCT ${ }^{*} b$ merged with the reflexes of PTpr/PCT ${ }^{*} \beta$ and PTpr/PCT ${ }^{*} o$ (before vowels) as pre-Wayoró ${ }^{*} \beta$, which yielded $/ \mathrm{m} /$ word-initially or after a nasal vowel and $/ \beta /$ after an oral vowel. The Tuparian etymologies which instantiate PTpr $* / \mathrm{m} /$ are listed in Table 9.

PTpr $* / \mathbf{n} /$. In nasal environments, PTpr $* / n /$ surfaced as ${ }^{*} n$ and was preserved as such in all daughter languages. In oral environments, it likely had the allophone ${ }^{*} n d$, which was preserved in Makurap but suffered some changes in the Core Tuparian languages. As stated 


\begin{tabular}{|c|c|c|c|c|c|c|}
\hline PTpr & gloss & Wayoró & Tuparí & Mekéns & Akuntsú & Makurap \\
\hline \multicolumn{7}{|c|}{ oral } \\
\hline${ }^{*} m b o$ & hand & $m b o /-\beta o$ & po & $p o(-p i)$ & po & $m b o$ \\
\hline *(n)õmbo- & $\begin{array}{l}\text { to kill, to beat } \\
\text { (CT only) }\end{array}$ & õmbo- & õpó- & $\tilde{o p o-}$ & $\tilde{o} p-a ́$ & - \\
\hline $\begin{array}{l}{ }^{*} \text { mboejop- } \\
{ }^{*} \text { mboec/to- } 57\end{array}$ & to know & mõẽndoP- & $p \mathcal{U}^{\prime}(2) O P-$ & poetop- & poetóP- & $\underline{\text { mboeto- }} \sim$ mbieto- \\
\hline${ }^{*} \mathrm{mboK} 2 a$ & $\begin{array}{l}\text { tortoise } \\
\text { (CT only) }\end{array}$ & $m b o g a$ & póк?a & poga & pogá & - \\
\hline${ }^{*} m b i\left(-t_{0}\right)$ & foot & $m b i /-\beta i$ & sitó & pitso & $p i$ & $m b i$ \\
\hline *ja:mbi & crop seed & $a \beta i$ & a:Psí & a:pi & - & $\underline{c a \tilde{m} b i}$ \\
\hline${ }^{*} m b i r o$ & $\begin{array}{l}\text { to have } \\
\text { (CT only) }\end{array}$ & mbiro & $-(P)$ síro & piro & - & - \\
\hline${ }^{*}$ mbiriza $^{58}$ & trahira fish & mbirija & sirizá & Sio piritsa & biritá & mbíria \\
\hline${ }^{*} m b i\{o$ & horsefly & - & sizó & - & - & mbio \\
\hline${ }^{*} m b i P$ & to be afraid & - & - & - & piP & $m b i P$ \\
\hline \multicolumn{7}{|c|}{ nasal } \\
\hline${ }^{*} m \tilde{a}-$ & to put & $m \tilde{a}-$ & $m \tilde{a}-$ & $m \tilde{a}-$ & $m \tilde{a}-$ & $m \tilde{a}-$ \\
\hline${ }^{*} m \tilde{a} \mu \tilde{\imath}$ & manioc & mãñ & $m \tilde{a} c$ & - & - & mẫñ \\
\hline${ }^{*} \tilde{a} m \tilde{a} n \tilde{a}$ & tayra & $\tilde{a} m \tilde{a} n \tilde{a}$ & - & - & - & ãmãnã \\
\hline${ }^{*} m \tilde{e} T^{59}$ & husband & $m \tilde{e} T$ & $m \tilde{e} T$ & $m \tilde{e} T$ & $m \tilde{e} T$ & - \\
\hline *mẽpiт & $\begin{array}{l}\text { child, sororal } \\
\text { nephew/niece } \\
\text { (female ego) }\end{array}$ & mẽpiT & mẽPsíT & mе̃piт & mẽpít & $\underline{\text { mẽpiT }}$ \\
\hline *mẽpir-ẽpiт & $\begin{array}{l}\text { grandchild } \\
\text { (female ego, } \\
\text { CT only) }\end{array}$ & mе̃pir-ẽpiT & $\begin{array}{c}\text { mẽPsĩr- } \\
\tilde{e} P s \tilde{i} T\end{array}$ & mе̃pir-ẽpiT & mе̃pir-ẽpíT & - \\
\hline *mẽ $\eta \tilde{\rho} P$ & $\begin{array}{c}\text { son-in-law } \\
\text { (daughter's } \\
\text { husband) }\end{array}$ & mе̃ & mẽeốP & - & - & $\underline{m \tilde{e} \eta \tilde{P} P}$ \\
\hline *amẽko & jaguar, dog & amẽko & amẽkó & amẽko & amẽkó & ämẽko \\
\hline${ }^{*} m \tilde{\imath} c \tilde{o}^{60}$ & curassow & - & - & - & - & mĩtố \\
\hline
\end{tabular}

Table 9. Proto-Tuparian */m/ (oral * $m b$, nasal ${ }^{*} m$ )

${ }_{57}$ The Core Tuparian languages unequivocally point to PCT *boeðoP- (in Wayoró, * $\succ$ nd nasalized the preceding vowels; in Tuparí, * роеоP- was apparently simplified to $\left.p_{\mathfrak{u}}(2)_{O P-}\right)$. However, the expected Makurap correspondence would be *mboecop- and not mboeto- $\sim$ mbieto-.

${ }^{58}$ The Wayoró reflex is from Galucio et al. (2015: 274), where it is given as mbirija, mbiridsa (with a transitional $j / \mathrm{n} /$ ). The expected reflex in Akuntsú would contain a /p/ and not a /b/; in fact, Galucio et al. (2015: 274) do give Akuntsú pirita (in our transcription, pirita), but our primary source has biritá (Aragon 2014: 109).

${ }^{59}$ Although no cognate in Makurap is known, PCT * $m \tilde{e} T$ can be securely traced back to PTpr * $m \tilde{e} T$ because precise external cognates are found all across Tupian (Karitiana mãn, Karo mẽn, PTG *mẽ ; Landin 2005: 16, Gabas Jr. 1999: 13, Mello 2000: 178).

${ }^{60}$ Although no cognate in the Core Tuparian languages is known, Makurap mitố can be securely traced back to PTpr *mĩcõ because precise external cognates are found all across Tupian (Karitiana mbisĩ , Proto-Mundurukú *wítõ, PTG *mütũ; Landin 2005: 16, Picanço 2019: 140, Mello 2000: 182). 


\begin{tabular}{|c|c|c|c|c|c|c|}
\hline PTpr & gloss & Wayoró & Tuparí & Mekéns & Akuntsú & Makurap \\
\hline \multicolumn{7}{|c|}{ oral } \\
\hline${ }^{*} n d i 2 a$ & lip color & - & súza & - & - & $\underline{n d i a}$ \\
\hline *(n)ẽndi & $\begin{array}{l}\text { mortar } \\
\text { (CT only) }\end{array}$ & end $\left\{\left\{d_{3} a\right\}\right.$ 'pestle' & $\tilde{e} T s \mathcal{u}-2 a$ & $\tilde{e} t s \dot{t}^{61}$ & - & - \\
\hline${ }^{*} n d \dot{i r i}$ & $\begin{array}{l}\text { collared } \\
\text { anteater }\end{array}$ & - & súrtu Stúru & - & - & $\underline{n d i r i}$ \\
\hline${ }^{*} n d o:$ & mound, hill & ndo: & to-téT & tso(:) & - & $n d o ́-a$ \\
\hline${ }^{*}$ ndeT- & to grind & ndeT- & teT- & - & - & ndeT- \\
\hline$*(j)$ aindi ${ }^{62}$ & wife & aindi & - & aitsi & ajtfi & - \\
\hline \multicolumn{7}{|c|}{ nasal } \\
\hline *ãmãnã & tayra & $\tilde{a} m \tilde{a} n \tilde{a}$ & - & - & - & ãmânnã \\
\hline *nãko & man & - & - & $n \tilde{a} k o^{63}$ & nãkó & $\underline{n a k k o-\beta i T}$ 'boy' \\
\hline *nõ & other & no & $n \tilde{}$ & no & no & $n \tilde{0}-T$ \\
\hline *ãnõrẽ ${ }^{64}$ & $\begin{array}{c}\text { barred } \\
\text { sorubim fish }\end{array}$ & ãnõrẽ & anốre & - & - & ãnốre \\
\hline${ }^{*} n \tilde{e}^{65}$ & arm & $\begin{array}{c}n \tilde{e}- \\
\text { (in compounds) }\end{array}$ & $\begin{array}{c}\{a\} n \tilde{e}-t o ́ \\
\text { 'shoulder' }\end{array}$ & $\begin{array}{c}n \tilde{e} \\
\text { 'shoulder' }\end{array}$ & - & $n \tilde{e}$ \\
\hline${ }^{*} n \tilde{e}-$ & to make & $n \tilde{e}-$ & $n \tilde{e}-$ & - & - & $n \tilde{e}-$ \\
\hline${ }^{*}$ ẽciK & horsefly & - & nẽuK & - & - & $\underline{n e \tilde{t} t K}$ \\
\hline
\end{tabular}

Table 10. Proto-Tuparian */n/ (oral *nd, nasal *n)

above, we believe it yielded PCT ${ }^{*} d$. In Tuparí and in the Corumbiara languages, it merged with the reflexes of PTpr/PCT ${ }^{*} t$ as Tupari $t$ (assibilated to $s$ before $i / \mathfrak{u}$ ), Mekéns $t s$, and Akuntsú $t$. In pre-Wayoró, PCT ${ }^{*} d$ became ${ }^{*}$ (merging with the reflexes of PTpr ${ }^{*} j>\mathrm{PCT}^{*}$ ), which yielded $n d / \mathrm{n} /$ in modern Wayoró. The Tuparian etymologies which instantiate PTpr */n/ are listed in Table 10.

PTpr */y/. PTpr */y/ quite probably surfaced as * $\eta g$ before nasal and oral vowels alike. This contrasts with the pattern we reconstruct for $* / \mathrm{m} /$ and $* / \mathrm{n} /$, whereby the postoralized realization is found in oral environments only. One piece of evidence comes from Tuparí,

${ }^{61}$ Attested as «enzề in Hanke et al. (1958: 204) and as ẽsi in Moore \& Galucio (1994: 134).

${ }^{62} \mathrm{PTpr}$ also likely had the compound *jąíp-ti 'wife' (literally, 'son's mother') preserved as Wayoró ndaip- $t i$ and Mekéns taip-si. In Tuparí and Makurap, *(j)aindi and *jaitip-ti appear to have contaminated: the former language has åtusi 'wife' (instead of the expected reflexes *aisi or *ha2uP-si); the latter has caip-ndi (instead of the expected reflexes ${ }^{*}(c)$ aindi or $\left.{ }^{*} c a i p-t i\right)$. The irregularities in the correspondences have been noted by Nogueira et al. (2019: 46), where the reconstruction *ai(+)tsi is given. Although PCT *aindi has no exact cognate in Makurap, it can

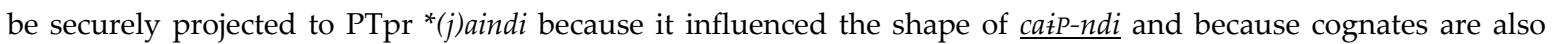
found elsewhere in Tupian (Proto-Mundurukú *tajtfi; Picanço 2019: 138).

${ }^{63}$ Attested in Hanke (1958: 206) as «nankú` 'man'. Galucio et al. (2015: 251) give nakop 'man' instead.

${ }^{64}$ Alves (2004: 145) claims that the Tuparí form is borrowed from Makurap, but there would appear to be no formal reason to believe so.

65 The Wayoró and Mekéns forms are attested in Snethlage (2015: 518, 686) as Wayoró 〈onänto’> 'Schulter',

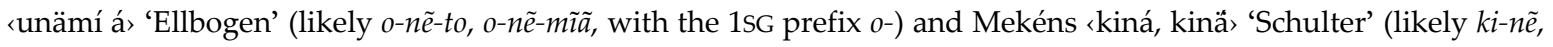

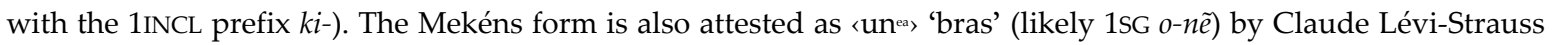
in his Kabišiana wordlist (apud Loukotka 1963: 48). 
Mekéns and Akuntsú, which reflect PTpr */y/ as $k$ regardless of whether the nucleus of the syllable is oral or nasal (unlike what we saw above for PTpr $* / \mathrm{m} /$ and $* / \mathrm{n} /$, which show a conditioned split in these three languages). Based on the correspondence between Wayoró $/ \mathrm{y} /, \mathrm{Tu}-$ parí $/ \mathrm{k} /$ and Mekéns/Akuntsú $/ \mathrm{k} /$, we may safely reconstruct $\mathrm{PCT}^{*}{ }^{*}$, which therefore differs from $\mathrm{PCT}^{*} b$ and ${ }^{*} d$ in occurring in oral and nasal environments indiscriminately. The second piece of evidence for reconstructing PTpr ${ }^{*} \eta g$ as the only realization of PTpr $* / \mathrm{y} /$ comes from Braga's (2005) transcriptions of Makurap words, in which / $\mathrm{y} /$ is transcribed as [' ${ }^{\mathrm{g}} \mathrm{g}$ even in na-

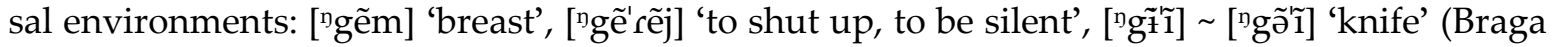
2005: 195-6). ${ }^{66}$ That way, PTpr * $\eta g$ (the only allophone of PTpr */y/) would have been preserved in Makurap. In PCT, it would have yielded ${ }^{*} g$, which was further devoiced to $k$ in Tuparí and in the Corumbiara languages (and merged with PCT * $k$, paralleling the merger of PCT ${ }^{*} p{ }^{*} b,{ }^{*} t{ }^{*} d$ in these languages). In Wayoró, ${ }^{*} g$ was probably lenited to pre-Wayoró ${ }^{*} \gamma$ (by means of the process which also lenited PCT ${ }^{*} b /{ }^{*} d$ to pre-Wayoró ${ }^{*} \beta{ }^{*} \delta$ ) and later nasalized to modern Wayoró /y/. Unlike in PTpr (in our reconstruction), however, the fully nasal realization of Wayoró /y/ in nasal environments is compulsory (Nogueira 2011: 50-1). The Tuparian etymologies which instantiate $\mathrm{PTpr} * / \mathrm{y} /$ are shown in Table 11.

\subsection{Innovative approximants in Proto-Corumbiara}

There is good reason to think that the proto-language of the Corumbiara branch acquired innovative approximants via hiatus resolution, whereby glides were inserted in the environment ${ }^{*} i, 0, \dot{i}_{-} V$. This includes both original hiatuses, retained from Proto-Tuparian, and new hiatuses, which arose as a result of elision of a PTpr glottal stop. Although the epenthesized segments are not phonetically approximants in the contemporary languages - rather, consonants such as $t, s$, or $k^{w}$ are found - we believe that these go back to erstwhile transitional glides, ${ }^{*} j$ (inserted in the environment $\left.{ }^{*} i_{-} V\right)$ and ${ }^{*} w\left({ }^{*} 0, \dot{t}_{-} V\right)$, which were subsequently fortitioned. That way, the epenthesis in pre-Proto-Corumbiara could be characterized as a natural sound change, glide epenthesis (Blevins 2008: 84sqq.), which fed another natural sound change, approximant fortition (independently established in subsections 3.1-2 above). The development pathway advanced in this subsection is thus essentially identical to Blust's (1994: 112-5) account of certain sound changes in a number of Austronesian languages (such as Chamorro), in which not only inherited approximants but also transitional/epenthetic glides have been historically fortitioned, as in Chamorro pugwa? 'betel nut', gwidza '3sG' (from *buaq, *ia; cf. also Blevins 2008: 92).

As was already mentioned above, we suggest that the consonant originally epenthesized in the environment ${ }^{*} i_{-} V$ in pre-Proto-Corumbiara was ${ }^{*} j$. In 3.2, we saw that PCT ${ }^{*} j$ - (from

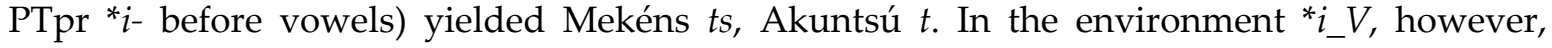
a slightly more complicated situation is found: at least in some words, the Guaratira and the Siokweriat dialects of Mekéns have $\varnothing$ corresponding to $t s$ in the Sakurabiat dialect (and to $t$ in Akuntsú). For example, Galucio et al. (2017: 338, fn. 6) report that pia 'to wait' is the form used in the Guaratira and Siokweriat dialects, which corresponds to pitsa in the Sakurabiat dialect. The Tuparian etymologies which instantiate Proto-Corumbiara $* j$ are shown in Table 12 . The Proto-Corumbiara reconstructions themselves are not given in the table for reasons of space; we reconstruct *kije 'one', *pija 'liver', *apija 'nose', *opija 'egg', *pirija 'trahira fish', *gwarija 'bat', *(a)mĩjã 'knee' (in the last word, Mekéns and Akuntsú have $n / n$ rather than ts/t, quite possibly due to the nasal environment).

${ }^{66}$ We assume that these transcriptions supersede Braga's earlier claim, according to which /y/ is obligatorily postoralized before oral vowels only (Braga 1992: 45-7). 


\begin{tabular}{|c|c|c|c|c|c|c|}
\hline PTpr & gloss & Wayoró & Tuparí & Mekéns & Akuntsú & Makurap \\
\hline \multicolumn{7}{|c|}{ oral } \\
\hline${ }^{*} \eta g a P$ & wasp & $\eta g a P$ & kaP & $k a P$ & $k a P$ & $\eta g a P$ \\
\hline${ }^{*}$ ygapi(-2a)67 & bullet ant & - & - & - & - & クgápia \\
\hline$* \eta g \dot{z}^{68}$ & liquid, saliva & $\eta g z$ & $k \mathcal{H}$ & $k \dot{z}$ & $k i$ & - \\
\hline${ }^{*} \eta g \dot{z} P$ & louse & $\tilde{a}-\eta g \mathcal{H} P$ & $k \mathfrak{H P}$ & $k \dot{t} P$ & $k \dot{t} P$ & $\eta g i p$ \\
\hline${ }^{*} \eta g \dot{z} 2 \dot{i} T$ & salt & $\eta g \mathcal{H}: T^{69}$ & kưźtT & $k \dot{i}: T$ & $? k \dot{t} C^{70}$ & $\eta g \dot{z} T$ \\
\hline *ygoPRi71 & termite & $\eta g u i$ & kóPZi & kobi & kopí & ? ygó $\beta-a$ \\
\hline${ }^{*} \eta g i p i z a^{72}$ & tick (CT only) & ygupi?a & - & - & kipíta & - \\
\hline${ }^{*} \eta g O T$ & palm larva & - & koT & - & - & クgoT \\
\hline *yge & garden & $\eta g e$ & - & - & - & $\eta g e$ \\
\hline *ygeat & sun, sky & ygiaT 'sky' & kiáT 'up' & - & - & クgéat \\
\hline${ }^{*} \operatorname{ygeK}^{73}$ & caterpillar & - & - & - & - & ygek \\
\hline *ygi-akoP & sun (CT only) & ygi-akoP & ki-akóP & $k i-a k o P$ & ki-akóP & - \\
\hline \multicolumn{7}{|c|}{ nasal } \\
\hline *nãygã & branch & - & $\tilde{a} k \tilde{a}$ & $\tilde{a} k \tilde{a}^{74}$ & - & hãygã \\
\hline${ }^{*} k \tilde{u} n \tilde{\imath} \eta g a^{75}$ & scorpion & $k \mathfrak{u}(\mathfrak{H}) n \tilde{\imath} \eta \tilde{a}$ & kwĩnīká & kĩnĩna & - & - \\
\hline${ }^{*} \eta g \tilde{e} P$ & breast & $\eta \tilde{e} P$ & $k \tilde{e} P$ & $k \tilde{e} P$ & $k \tilde{e} P$ & $\eta g \tilde{e} P$ \\
\hline $\begin{array}{c}{ }^{*} \eta g \tilde{e} T- \\
* \eta g \tilde{e} T-\eta g a-\end{array}$ & $\begin{array}{l}\text { to sink } \\
\text { to swallow } \\
\text { (WT only) }\end{array}$ & $\begin{array}{c}\eta \tilde{e} T- \\
\eta \tilde{e} T-\eta g a-\end{array}$ & $k e \tilde{T}-k a$ & - & - & - \\
\hline
\end{tabular}

Table 11. Proto-Tuparian */y/ (oral and nasal * $y g$ )

${ }^{67}$ Although no cognate in Core Tuparian is known, Mak ygápia can be securely traced back to PTpr * $\eta g a p i(-2 a)$ because an external cognate is found in Karitiana (nõpi 'bullet ant', Landin 2005: 19). Karitiana $n$ is a regular reflex of Proto-Tupian ${ }^{*} \eta$ in nasal environments, but the mismatch between the nasality values of the first syllable in Makurap and Karitiana awaits further explanation.

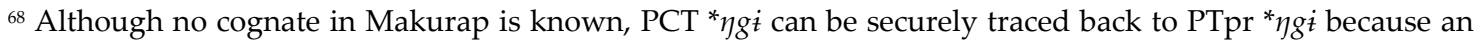
external cognate is found in Karitiana ( $\eta g e$ 'blood', Landin 2005: 9).

${ }^{69}$ Form attested in Moore \& Galucio (1994: 134). Nogueira (2011: 40) documents a form with an initial k-, which could be a mistranscription or a borrowing from another Tuparian language.

${ }^{70} \mathrm{It}$ is unclear if this is an irregular reflex of * $\eta g \dot{z} 2 \dot{i} T$ or a semantic extension of $k \dot{i} C$ 'earth' $\left(<\mathrm{PTpr}{ }^{*} k \dot{i C}\right)$.

71 The Wayoró and Mekéns forms are cited after Galucio et al. (2015: 272); the expected Wayoró reflex would actually be ${ }^{*} \eta g o \beta i$. It is uncertain if the Makurap word is a precise cognate because of the vowel mismatch; it is possible that continues a derivative close to * $\eta g o p ? i-\{a$ (compare Proto-Mundurukú *kópiã 'blood', Sateré-Mawé nupiza; Picanço 2019: 138, Ribeiro 2010: 76).

72 The Wayoró form is from Galucio et al. (2015: 273).

${ }^{73}$ Although no cognate in Core Tuparian is known, Mak $\eta g e K$ can be securely traced back to PTpr * $\eta g e K$ because an external cognate is found in Karitiana ( $\eta g a k$ 'caterpillar', Landin 2005: 9).

${ }^{74}$ The form is tentatively phonologized based on Snethlage's (2015: 520) attestation of ‘zānka〉 'Zweig' (likely the third person $t s-\tilde{a} k \tilde{a})$.

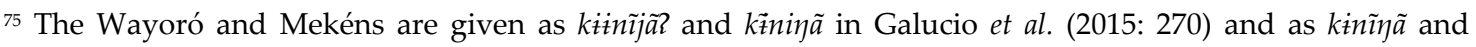
kitnĩyã in Moore \& Galucio (1994: 134); our phonologization is tentative. In Tuparí, the vowel of the first syllable is irregularly diphthongized $\left({ }^{*} \tilde{t}>w \tilde{\imath}\right)$, assuming our primary source (Alves 2004: 204) records the word correctly; in Mekéns, we would expect a $/ \mathrm{k} /$ rather than a $/ \mathrm{h} /$. The stem is likely inherited from Proto-Tuparian (as opposed to a Core Tuparian innovation), because there is a probable cognate in Karitiana: kennõn 'scorpion' (Landin 2005: 13) <

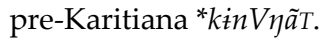




\begin{tabular}{|c|c|c|c|c|c|c|}
\hline PTpr & gloss & Wayoró & Tuparí & Mekéns & Akuntsú & Makurap \\
\hline${ }^{*}$ kie & one (CT only) & kie-T & kie & $\begin{array}{c}\text { kitse, kie }\{k a\} \\
\text { Sio gie }{ }^{76}\end{array}$ & kite & - \\
\hline *piza & liver & pia & sizá & pitsa & bita & pía \\
\hline *nãpi(2a) & nose & ãpia & $\tilde{a} P s i ́$ & ãpitsa & ãpíta & nâpi \\
\hline *jopiza & egg & upia & opsíza & opitsa & opita & cópia \\
\hline${ }^{*}$ mbiriza $a^{77}$ & trahira fish & mbirija & sirizá & Sio piritsa & biritá & mbiria \\
\hline${ }^{*}$ wariza & bat (CT only) & $\eta g^{w}$ aria & wáriza & $\begin{array}{c}k^{w} \text { aritsa } \\
\text { Sio } k^{w} \text { aritsa } \sim g^{w}-\end{array}$ & - & (Bacáriac) \\
\hline *-pĩa & knee & $\{k \tilde{u}\} m \tilde{\imath} \tilde{a}$ & $m \tilde{\imath} \tilde{a}\{K-\{\tilde{a}\}$ & \{nẽkiwa\}mĩna 'elbow' & $\{a\} m i n a \tilde{a}$ & $\{k a\}$ pĩa \\
\hline
\end{tabular}

Table 12. Proto-Corumbiara *j (> Sakurabiat $t s$, Guaratira/Siokweriat $\varnothing$, Akuntsú $t$ )

It is interesting to observe that in the variety of Mekéns attested by Wanda Hanke the consonant in question is consistently transcribed as $\langle\mathrm{Z}\rangle$ (more rarely, $\langle\mathrm{S}\rangle)$, which implies that she must have made her notes with speakers of the Sakurabiat dialect: 〈kitzê〉 'one', 〈-piza〉 'liver', 〈ampiza〉 'nose', 〈kurakura-rupiza〉 'egg' (korakora 'hen'), 〈kwarisa, kwarisasu〉 'bat' (Hanke et al. 1958). In contrast, Emil-Heinrich Snethlage’s notes on Mekéns typically have zero: <-piá> 'liver', 〈-åmpiá> 'nose', <-upiá〉 'egg'; one exception is ‘kízäkántn〉 'one' (Snethlage 2015: 518-20).

Curiously, not all instances of Sakurabiat $t s \sim$ Guaratira/Siokweriat $\varnothing$ reflect an erstwhile epenthetic glide. At least in two words, this correspondence continues PTpr/PCT ${ }^{*} t>$ ProtoCorumbiara *ts. One example is the word for 'foot', which has the shape pitso in Sakurabiat, but pio in Guaratira and Siokweriat (Galucio 2001: 19); the Tuparí cognate sito 'foot' shows that all these words continue PCT *bito (ultimately derived from PCT ${ }^{*} b i<$ PTpr * $m b i$ 'foot'). Similarly, Galucio (2011b:7, fn. 11) states that the 1INCL pronoun is kitse in Sakurabiat but okie in Guaratira and Siokweriat (<PTpr $\left.{ }^{*} k i t e\right)$.

Now we turn to the environment ${ }^{*} 0, \dot{t}_{-} V$. We believe that such hiatuses were resolved in pre-Proto-Corumbiara by means of the insertion of ${ }^{*} w$ (merging with $\mathrm{PTpr} / \mathrm{PCT}{ }^{*} w$ ), which yielded Mekéns/Akuntsú $k^{w}$. Curiously enough, the Wayoró cognates of these words also have $k^{w}$, which must be attributed to an independent innovation. The Tuparian etymologies which instantiate pre-Proto-Corumbiara ${ }^{*} w$ are shown in Table 13.

\begin{tabular}{|c|c|c|c|c|c|c|}
\hline PTpr & gloss & Wayoró & Tuparí & Mekéns & Akuntsú & Makurap \\
\hline *jo(2)a & $\begin{array}{c}\text { brother } \\
\text { (female ego) }\end{array}$ & $o k^{w} a$ & owwá oqá & $o k^{w} a$ & $o k^{w} a ́$ & cóa \\
\hline${ }^{*}$ joac & tail & $o k^{w} a c$ & oác & $o k^{w} a c$ & $o k^{w} a ́ c$ & пёт-соас \\
\hline${ }^{*} O 2 e^{78}$ & to wash & $o k^{w}-a ́$ & oqé & $o k^{w}-a$ & $\tilde{o} k^{w}-a$ & $o ́-a$ \\
\hline *ia:C & tapir & $u k^{w} a: c$ & - & $i k^{w} a: c$ & $i k^{w} a ́ c$ & iác \\
\hline
\end{tabular}

Table 13. Pre-Proto-Corumbiara ${ }^{*} w>$ Mekéns/Akuntsú $k^{w}$

${ }^{76}$ The forms kitse and kieka are cited after Galucio et al. (2015: 250); we would expect kitse to be from the Sakurabiat dialect and kieka from the Guaratira dialect. Siokweriat [gie] is cited after Áragon (2014: 310); we would expect it to be kie.

77 The Wayoró reflex is from Galucio et al. (2015: 274), where it is given as mbirija, mbiritsa (with a transitional $j / \mathrm{n} /$ ). The expected reflex in Akuntsú would contain a /p/ and not a /b/; in fact, Galucio et al. (2015: 274) do give Akuntsú pirita (in our transcription, pirita), but our primary source has biritá (Aragon 2014: 109).

${ }_{78}$ The stem without the thematic vowel is attested only in Tuparí. Braga (2005: 196) gives the stem without the thematic vowel as $O P$, but it is not attested in any linguistic example and does not match the Tuparí form. 
Even though only one example is known for the environment ${ }^{*} \dot{i}_{-} V$, the ${ }^{*} w$-epenthesis must have been regular. No reflexes of PTpr *iaT 'grass, lawn' (> Tuparí \#áT 'lawn', Makurap $\underline{\dot{z} a T}$ 'grass') are attested in Wayoró or in the Corumbiara languages (we would expect them to have the shape ${ }^{*} u k^{w} a T$ in Wayoró and ${ }^{*} i k^{w} a T$ in Mekéns/Akuntsú). The correspondence between Wayoró ußeko:P, Akuntsú iekó, Mekéns ieko, and Makurap íéko, all meaning 'king vulture', appears to be, therefore, irregular (especially regarding the Wayoró form), suggesting that this word has been diffused via horizontal transmission in the region.

\section{Evolution in the daughter languages}

In this section, we outline the evolution of the consonantal onsets of Proto-Tuparian in the daughter languages (except those which arose from erstwhile codas via resyllabification).

Proto-Tuparian to Makurap. The evolution of the Proto-Tuparian onsets in Makurap involves as few as four innovations: (i) fortition of the approximants ${ }^{*} \beta$ and ${ }^{*} j$ to Mak $p, c$ (3.1); (ii) loss of the velar articulation in ${ }^{*} w$, which became Mak $\beta / m$ (as per nasality of the nucleus); (iii) fronting of ${ }^{*} \mathrm{C}$ into Mak $t$; (iv) consonantization of the prevocalic instances of ${ }^{*} i$ into $n d z / n$ (as per nasality of the nucleus), as in the third person prefix ${ }^{*} i-$ (3.2). Note that PTpr ${ }^{*} n$ remained in Makurap as $n$, but its phonological status appears to have changed: it is analyzed as the nasal allophone of $* / \mathrm{j} /$ in Proto-Tuparian, but as the nasal allophone of $* / \mathrm{n} /$ in Makurap due to the influx of $n d z$ (from earlier * $i$ before vowels). This is shown in Figure 1.

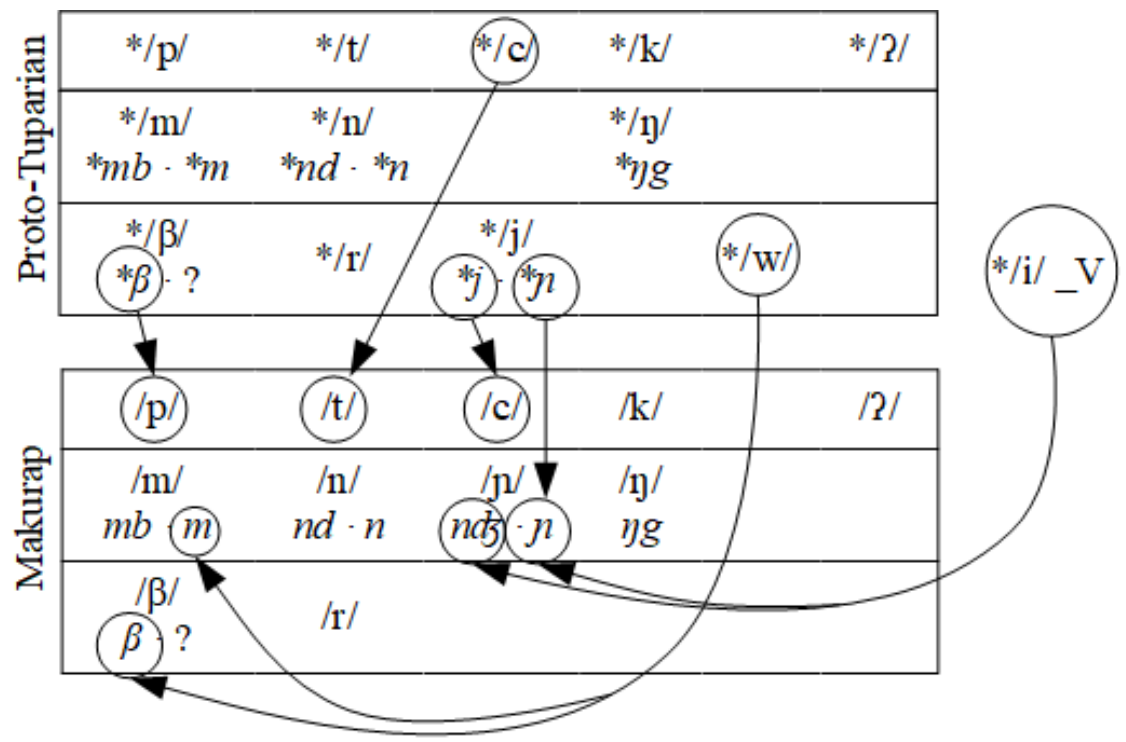

Figure 1. Evolution of the Proto-Tuparian onsets in Makurap

Proto-Tuparian to Proto-Core Tuparian. The Proto-Tuparian onsets have evolved in the following way in Proto-Core Tuparian: (i) the postoralized allophones of PTpr underlying nasal stops $\left({ }^{*} m b / \mathrm{m} /,{ }^{*} n d / \mathrm{n} /,{ }^{*} \eta g / \mathrm{n} /\right)$ lose their nasal phase and become PCT ${ }^{*} b,{ }^{*} d,{ }^{*} g$ (3.3); (ii) PTpr ${ }^{*} p$ and ${ }^{*} t$ nasalize to PCT ${ }^{*} m$ and ${ }^{*} n$ preceding nasal nuclei; (iii) ${ }^{*} j$ dentalizes to PCT ${ }^{*} \delta$ (3.1); (iv) in some polysyllabic relational stems, the stem-initial*/j/ disappears; (v) the prevocalic instances of $* i$ consonantize to $j / \eta$ (as per nasality of the nucleus), as in the third person prefix ${ }^{*} i$ - (3.2); (vi) ${ }^{*} w$ loses its labial articulation preceding rounded vowels and becomes ${ }^{*} \gamma$ 
(phonologically, still an allophone of $* / w /$ ). Note that in PCT the voiced stops ${ }^{*} b$ and ${ }^{*} d$ occurred in oral environments only and were thus in a complementary distribution with PCT ${ }^{*} m$ and ${ }^{*} n$. We tentatively analyze PCT ${ }^{*} b /{ }^{*} m$ and ${ }^{*} d /^{*} n$ as allophones of underlying $* / b /$ and ${ }^{*} / \mathrm{d} /$ conditioned by the nasality of the nucleus, but other solutions cannot be at present ruled out. The evolution of the Proto-Tuparian onsets in Proto-Core Tuparian is schematized in Figure 2.

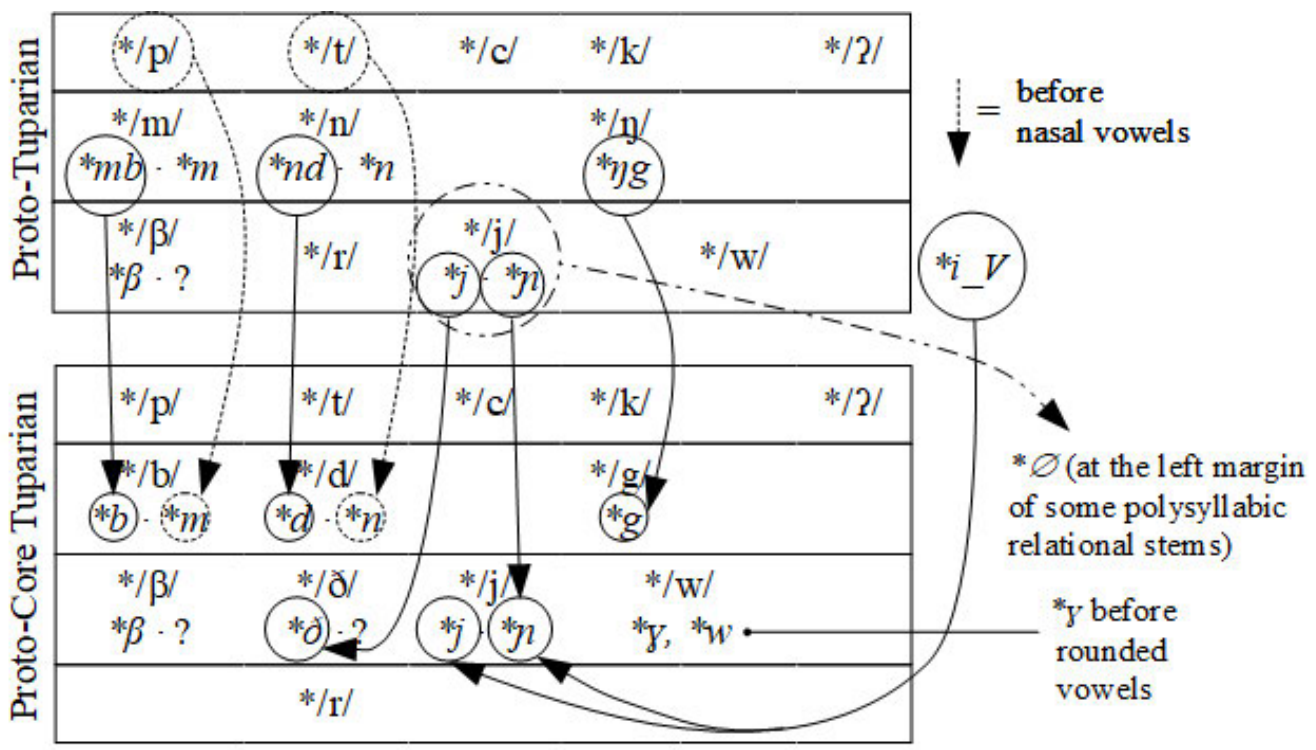

Figure 2. Evolution of the Proto-Tuparian onsets in Core Tuparian

Proto-Core Tuparian to Wayoró. For an accurate description of the evolution of the PCT onsets in Wayoró, it is useful to distinguish between two chronological stages, which we dub pre-Wayoró and Wayoró. In pre-Wayoró, PCT ${ }^{*} b,{ }^{*} d$, and ${ }^{*} g$ were lenited to ${ }^{*} \beta,{ }^{*} \delta$, and ${ }^{*} \gamma$, thus merging with pre-existing PCT ${ }^{*} \beta,{ }^{*} \delta$, and ${ }^{*} \gamma(3.3)$. Note that ${ }^{*} \gamma$ is analyzed as an allophone of $* / \mathrm{w} /$ in PCT, where its occurrence was conditioned by a following rounded vowel. In preWayoró, however, ${ }^{*} / \gamma /$ and $* / \mathrm{w} /$ are contrastive thanks to the influx of ${ }^{*} \gamma<$ PCT ${ }^{*} g$ (compare pre-Wayoró *weP- 'to climb' and * $\gamma e$ 'garden'). Another minor source of pre-Wayoró * $\beta$ is PCT ${ }^{*} O$ before vowels (notably in the 1 SG prefix ${ }^{*} O-; 3.2$ ).

After the completion of these processes, the approximant-rich sound system of preWayoró suffered further changes. Namely, pre-Wayoró ${ }^{*} \beta,{ }^{*} \delta,{ }^{*} j,{ }^{*} \gamma,{ }^{*} w$ were fortitioned to $m b$, $n d, n d 3, \eta g, \eta g^{w}$ in oral environments and to $m, \eta, \eta^{w}$ in nasal environments (no examples are available for pre-Wayoró ${ }^{*} \partial$ or ${ }^{*} j$ in nasal environments); exceptionally, ${ }^{*}-\beta$ - and ${ }^{*}-j$ - between vowels yielded $-\beta$ - and $-d 3^{-}$in modern Wayoró. Synchronically, Nogueira (2019) analyzes $m b$, $n d, n d 3, \eta g, \eta g^{w}$ as allophones of underlying /m n n n $\mathrm{n}^{\mathrm{w}} /$, which are thus derived via nasal shielding (Wetzels \& Nevins 2018). ${ }^{79}$

79 Although we provisionally accept Nogueira's (2019) analysis in this paper, there appear to be serious arguments for alternatively analyzing Wayoró $m b, n d, n d z, \eta g, \eta g^{w}$ as allophones of voiced stops $/ \mathrm{b} \mathrm{d} \mathrm{d}_{3} \mathrm{~g} \mathrm{~g}^{\mathrm{w}} / \mathrm{derived}$ via nasal venting (Wetzels \& Nevins 2018). Note that $m b, n d 3, \eta g$, and $\eta g^{w}$ may only occur word-initially and after nasal vowels; between oral vowels, $\left[\beta \mathrm{d}_{3} \mathrm{~g} \mathrm{~g}^{\mathrm{w}}\right]$ occur (Nogueira 2019: 8, 62, fn. 1). This distribution matches perfectly all four predictions made by Wetzels \& Nevins (2018: 842) for nasal venting, including (i) the absence of prenasalized voiceless consonants; (ii) the absence of prenasalized fricatives; (iii) the decreasing susceptibility of consonants to nasal venting as one moves from velars to labials (as in pre-Wayoró *aftuP 'louse', *ewiT 'honey', *eðut 'marico bag' > $\tilde{\eta} g \mathcal{H} P$, $\tilde{e} \eta g^{w} i T$, end $\mathfrak{t}$, but * $a \beta i$ 'seed' > $\left.a \beta i\right)$; and (iv) greater prominence of the nasal venting in prosodic domain-initial position as compared to the intervocalic position (compare * $\beta o$ 'hand' > mbo, but *o- $\beta o$ 'my hand'> 
The epenthesis of $k^{w}$ in the environment $0, \psi_{-} V$ must have proceeded through the stage ${ }^{*} o w V /{ }^{*} \mathfrak{w} W V$; that way, a glide was inserted and subsequently fortitioned. Both processes must have applied after the sound change ${ }^{*} w>\eta(g)^{w}$, because otherwise we would expect tokens such as PTpr ${ }^{*} \dot{i}: \mathrm{C}>>$ pre-Wayoró ${ }^{*} \mathfrak{H a}: \mathrm{C}$ 'tapir' to have participated in them, yielding ${ }^{*} \mathfrak{H} w a: C>$ ${ }^{*} \tilde{\mathfrak{t}} \eta g^{w} a: C$ (rather than the attested $\mathfrak{H}^{w} a: C$ ).

Finally, the change from $\mathrm{PCT}{ }^{*} \mathrm{C}$ to Wayoró $t \int$ has not involved any phoneme splits or mergers and cannot be straightforwardly attributed to any specific chronological level. In fact, it is not even clear whether any sound change has been involved at all, because almost nothing is known about the articulation of $\mathrm{PTpr} / \mathrm{PCT}{ }^{*} \mathrm{c}$ other than that it was a voiceless coronal segment capable of changing to $t$, $t$, or $\varnothing$. In Figure 3 below, it has been provisionally attributed to the pre-Wayoró stage, but it should be kept in mind that other scenarios are also possible.

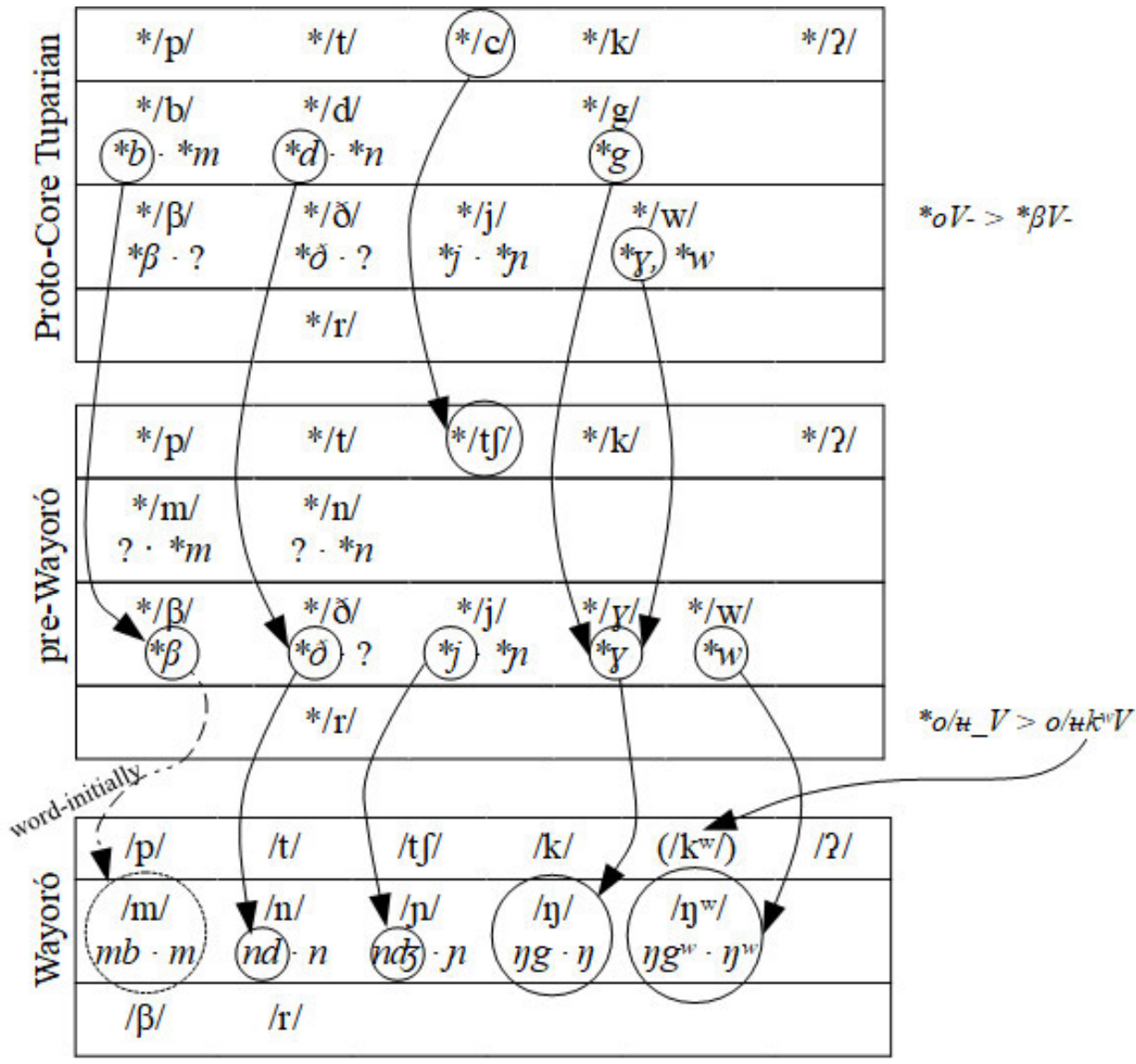

Figure 3. Evolution of the Proto-Core Tuparian onsets in Wayoró

Proto-Core Tuparian to Tuparí. The phonological history of Tuparí is characterized by multiple mergers, which resulted in the loss of the original voice distinctions reconstructed for Proto-Core Tuparian, as well as by a number of palatalization processes. A full list of the innovations we could identify follows: (i) mergers of ${ }^{*} p{ }^{*} b /{ }^{*} \beta>{ }^{*} p,{ }^{*} t{ }^{*} d>{ }^{*} t,{ }^{*} k{ }^{*} g>{ }^{*} k(3.1,3.3)$; (ii) ${ }^{*} p$ is palatalized before $i$ to $-P S$ - (between vowels) or $s$ - (elsewhere); (iii) ${ }^{*} t$ is palatalized to $s$

$o-\beta o$ ). Future studies in Wayoró phonology should determine whether it is possible to posit the phonemes $/ \mathrm{b} \mathrm{d} \mathrm{d} 3$

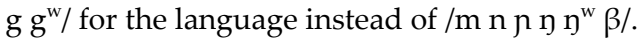


before $i / \mathfrak{H}$; (iv) ${ }^{*} j$ is fortitioned to $s$ (3.2) but its nasal counterpart $\mu$ stays except before $\tilde{\imath}$, where it is deleted (3.1); (v) ${ }^{*} \gamma$ is debuccalized to $h$ word-initially and disappears between vowels (3.1); (vi) ${ }^{*} \gamma$ (an allophone of PCT $* / w /$ ) is deleted (3.1); (vii) ${ }^{*} c$ is deleted at least between vowels; (viii) PCT ${ }^{*} O$ is consonantized to $w$ before unrounded vowels and fuses with following rounded vowels yielding long vowels (notably in the 1 SG prefix ${ }^{*}{ }^{*} ; 3.2$ ). This is schematized in Figure 4 below.

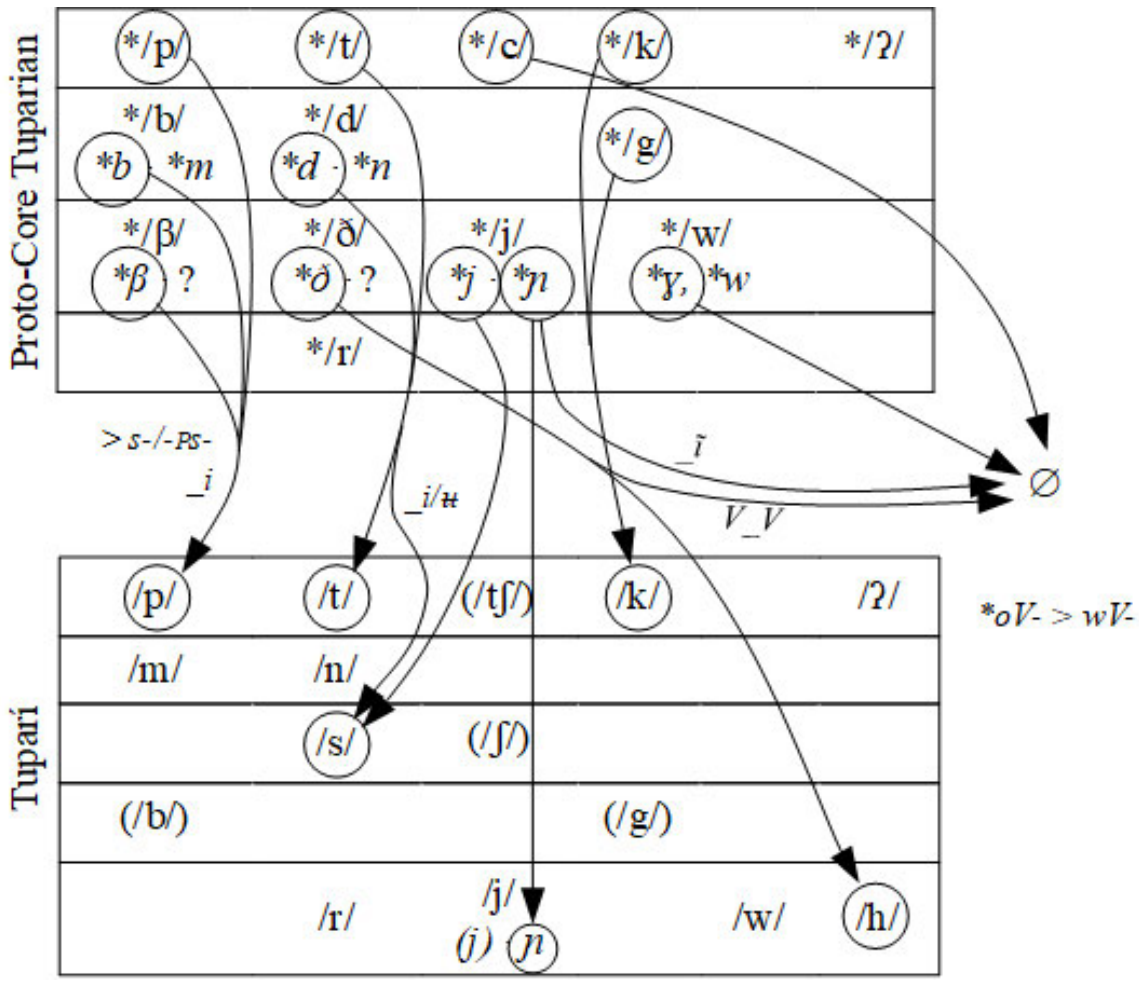

Figure 4. Evolution of the Proto-Core Tuparian onsets in Tuparí

Proto-Core Tuparian to Mekéns/Akuntsú. It is convenient to present the evolution of the Proto-Core Tuparian onsets in the Corumbiara languages Mekéns and Akuntsú by dividing the phonological history of these languages into two stages. At stage 1, a chain shift affects the voiced oral segments of PCT: the approximants ${ }^{*} \beta,{ }^{*} \delta,{ }^{*} \gamma,{ }^{*} w$ become voiced stops $\left({ }^{*} b,{ }^{*} d,{ }^{*} g\right.$, ${ }^{*} g^{w}$; 3.1), whereas the PCT voiced stops lose voice $\left({ }^{*} b,{ }^{*} d,{ }^{*} g>{ }^{*} p,{ }^{*} t,{ }^{*} k\right.$; 3.3). These processes are also fed by the glide insertion (PCT $\left.{ }^{*} i_{-} V,{ }^{*} o / i_{-} V>{ }^{*} i j V,{ }^{*} o / i w V ; 3.4\right)$. At stage $2,{ }^{*} t$ becomes an affricate (Proto-Corumbiara ${ }^{*} t s>$ Mek $t s$, Aku $t$ )). Innovative Proto-Corumbiara ${ }^{*} t(>\mathrm{Mek} / \mathrm{Aku} t$ ) comes from two sources: fronting of ${ }^{*} c>{ }^{*} t$ and devoicing of ${ }^{*} d /{ }^{*} g /{ }^{*} g^{w}>{ }^{*} t{ }^{*} k{ }^{*} k^{w}$. The latter process occurred in all Corumbiara varieties, with the proviso that in the history of the Sakurabiat dialect it was bled by the nasalization of voiced stops in nasal environments (as in

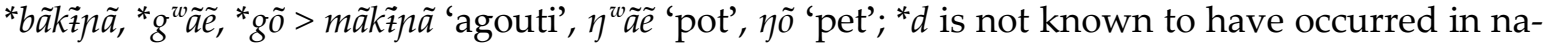
sal environments). In other dialects of Mekéns and in Akuntsú, there was no nasalization of voiced stops, and the devoicing of ${ }^{*} d /^{*} g /{ }^{*} g^{w}$ applied categorically.

Fortition and devoicing also affected pre-Proto-Corumbiara ${ }^{*} j$, which yielded ts in Sakurabiat and $t$ in Akuntsú. Based on these reflexes, one could be tempted to reconstruct ProtoCorumbiara ${ }^{*}$, which would have been subsequently devoiced to ${ }^{*} c>$ Sak $t s$, Aku $t$. However, the fact that the Guaratira and Siokweriat dialects of Mekéns have $\varnothing$ corresponding to Sak ts, Aku $t$ in the environment $i_{-} V$, implies that the fortition of ${ }^{*} j$ must have occurred only recently 
in the history of the Corumbiara languages: while the sound change ${ }^{*} i j V>i V$ is easily conceivable, it would be more difficult to account for a sound change such as ${ }^{*} i c V,{ }^{*} i_{f} V$, or ${ }^{*} i t s V>i V$. A detailed reconstruction of the evolution of ${ }^{*} j$ in the Corumbiara languages awaits further investigation.

Figure 5 summarizes our proposal regarding the development of the PCT onsets in Mekéns and Akuntsú.

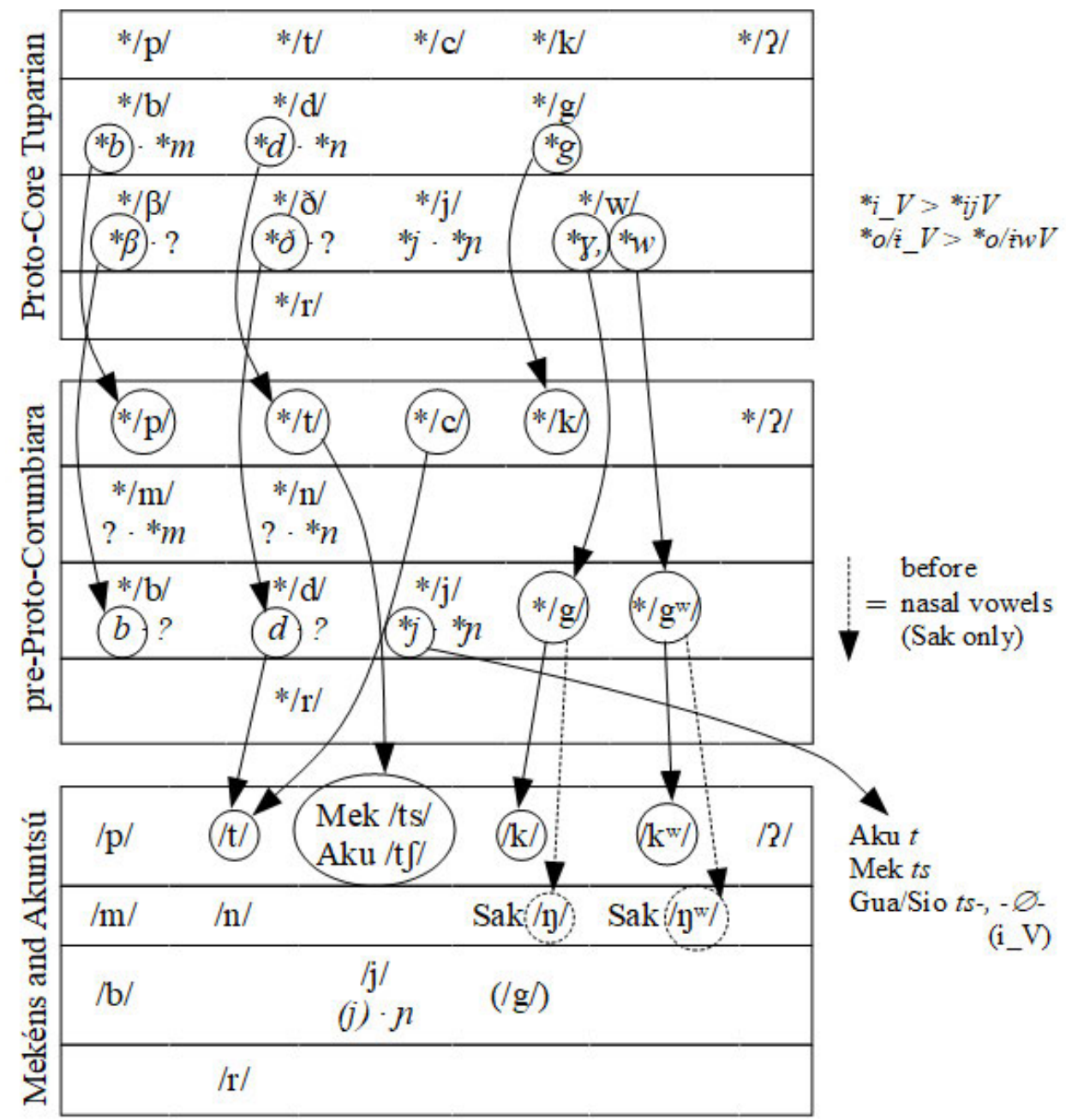

Figure 5. Evolution of the Proto-Core Tuparian onsets in Mekéns and Akuntsú

\section{Conclusions}

This paper has advanced the reconstruction of the evolution of a number of Proto-Tuparian segments in daughter languages, with a focus on the Proto-Tuparian approximants as well as on sounds which went through an approximant stage at least in some Tuparian languages. Compared to earlier works on the historical phonology of this genetic unit, our proposal stands out in taking into account its subgrouping, thus allowing us to identify crucial innovations restricted to specific clades (such as Core Tuparian and Corumbiara), as well is in considering important data sources which have become available only recently (notably Aragon 2014; Singerman 2016, 2018; Nogueira 2019). 
Future research on the historical phonology of Proto-Tuparian should address issues such as the evolution of the Proto-Tuparian glottal stop (which is known to frequently disappear in the daughter languages under unknown conditions), the coda resyllabification patterns, the reconstruction of vowel length in Proto-Tuparian, and the reconstruction of the ProtoTuparian prosody (which should minimally account for the contrastive stress in Tuparí and Akuntsú and for the tonal patterns of Makurap).

It is hoped that this study will inform further comparative research of the entire Tupian family, and we believe that at least some of our results are of interest to the typology of sound change (cf. Blevins 2008) and phonological theory (cf. Wetzels \& Nevins 2008).

\begin{tabular}{|c|c|c|}
\hline \multicolumn{3}{|c|}{ Abbreviations } \\
\hline $\mathrm{ku}=\mathrm{Akuntsú}$ & PCor $=$ Proto-Corumbiara & $1 / 3=$ first/third person \\
\hline Sua $=$ Guaratira & PCT $=$ Proto-Core Tuparian & CAUS $=$ causative \\
\hline Kup = Kupndiiriat & PTG = Proto-Tupí-Guaraní & $\mathrm{FOC}=$ focus \\
\hline Mak = Makurap & PTpr = Proto-Tuparian & DIFF $=$ diffuse locative \\
\hline Mek = Mekéns & PWT $=$ Proto-Wayoró-Tuparí & $\mathrm{INCL}=$ inclusive \\
\hline $\mathrm{Jgw}=$ Ngwayoroiat & & LOC $=$ locative \\
\hline ak = Sakurabiat & & $\mathrm{NCRF}=$ non-coreferential \\
\hline io $=$ Siokweriat & & $\mathrm{PL}=$ plural \\
\hline up = Tuparí & & POSS $=$ possessed \\
\hline Vay $=$ Wayoró & & $\mathrm{PST}=$ past \\
\hline & & $\mathrm{SG}=$ singular \\
\hline & & $\mathrm{TH}=$ thematic vowel \\
\hline
\end{tabular}

\section{References}

Alves, Ana Carolina, Ana Vilacy Galucio. 2007. Análise fonética acústica das vogais orais da língua Sakurabiat. Letras de Hoje 42(3): 27-42.

Alves, Poliana Maria. 2004. O léxico do Tuparí: proposta de um dicionário bilíngüe. Ph.D. dissertation, Universidade Estadual Paulista "Júlio de Mesquita".

Anonymous. No date. Palavras e frases da lingua Wyarú. Rio de Janeiro, manuscript (personal archive of Darcy Ribeiro).

Aragon, Carolina Coelho. 2008. Fonologia e aspectos morfológicos e sintáticos da língua Akuntsú. MA thesis, Universidade de Brasília.

Aragon, Carolina Coelho. 2014. A grammar of Akuntsú, a Tupian language. Ph.D. dissertation, University of Hawai 'i at Mānoa.

Aragon, Carolina Coelho, Ana Suelly Arruda Câmara Cabral. 2005. A posição da língua Akuntsú na família lingüística Tuparí. In: Lúcia Maria Pinheiro Lobato; Stella Maris Bortoni-Ricardo; Ana Suelly Arruda Câmara Cabral; Heloisa Maria Moreira Lima Salles; Maria Marta Pereira Scherre; Daniele Marcelle Grannier (orgs.). Anais do IV Congresso Internacional da ABRALIN: 1533-9. Brasília: Universidade de Brasília.

Aragon, Carolina Coelho, Fernando O. de Carvalho. 2007. Análise acústica das vogais orais da língua Akuntsú. Revista da ABRALIN 6(2): 41-55. doi:10.5380/rabl.v6i2.52623

Aragon, Carolina Coelho, Luciana Keller Tavares. 2019. Aspectos da cultura material do povo Akuntsú. Paper presented at the $3^{\circ}$ Congresso Internacional Povos Indígenas da América Latina (CIPIAL). Brasília: Universidade de Brasília. Retrieved from: <https://www.academia.edu/39865327/Aspectos_da_cultura_ material_do_povo_Akunts\%C3\%BA>, accessed on 02/07/2020.

Becker-Donner, Etta. 1955. Notizen über einige Stämme an den rechten Zuflüssen des Rio Guaporé. Archiv für Völkerkunde 10: 275-343. 
Blevins, Juliette. 2008. Consonant epenthesis: natural and unnatural histories. In: Good, Jeff (ed.). Linguistic Universals and Language Change: 79-107. Oxford University Press.

Blust, Robert. 1994. Obstruent epenthesis and the unity of phonological features. Lingua 93(2-3): 111-139. doi:10.1016/0024-3841(94)90001-9

Bontkes, Willem. 1978. Dicionário preliminar Suruí-português, portugués-Suruí. Porto Velho: Summer Institute of Linguistics.

Braga, Alzerinda. 1992. A fonologia segmental e aspectos morfofonológicos da língua Makurap (Tupí). MA thesis, Universidade Estadual de Campinas.

Braga, Alzerinda. 2005. Aspects morphosyntaxiques de la langue Makurap/Tupi. Ph.D. dissertation, Université de Toulouse-Le Mirail.

Caldas, Raimunda Benedita Cristina. 2009. Uma proposta de dicionário para a língua Ka'apór. Ph.D. dissertation, Universidade de Brasília.

Carvalho, Fernando O. de. 2019. Revisitando o Proto-Jurúna: A reconstrução das oclusivas orais. In: Edna dos Santos Oliveira, Eduardo Alves Vasconcelos, Romário Duarte Sanches (eds.). Estudos linguísticos na Amazônia: 215-236. Campinas: Pontes Editores.

Carvalho, Fernando O. de. Forthc. The Historical Phonology of the Tupi-Guarani Language Family (working title). Berlin: Language Science Press.

Chacon, Thiago Costa. 2012. The phonology and morphology of Kubeo: The documentation, theory, and description of an Amazonian language. Ph.D. dissertation, University of Hawai'i at Mānoa.

Corbera Mori, Ángel. 2008. Aspectos da fonologia segmental Mehináku (Aruák). Estudos Lingüísticos 37(1): 63-72.

Corrêa-da-Silva, Beatriz Carretta. 2010. MawélAwetí/Tupí-Guaraní: relações lingüísticas e implicações históricas. Ph.D. dissertation, Universidade de Brasília.

Drude, Sebastian. 2009. Nasal harmony in Awetí: a declarative account. ReVEL - Revista Virtual de Estudos Da Linguagem 3.

Epps, Patience. 2020. South American Languages. In: Claire Bowern, Patience Epps, Jane Hill, Patrick McConvell. Languages of Hunter-Gatherers and their Neighbors: Database. Retrieved from <https://huntergatherer.la. utexas.edu>, accessed in 19/07/2020.

Gabas Jr., Nilson. 1999. A Grammar of Karo, Tupi (Brazil). Ph.D. dissertation, University of California, Santa Barbara.

Gabas Jr., Nilson. 2005. Classificação da língua Akuntsú. Estudos Lingüísticos 36: 105-10.

Galucio, Ana Vilacy. 1994. Fonologia segmental da língua Mekens. In: Anais do IX Encontro Nacional da ANPOLL (Caxambu, junho de 1994). Área de Lingüística, v. 2: 988-97. João Pessoa: Associação Nacional de Pós-Graduação e Pesquisa em Letras e Lingüística, 1994.

Galucio, Ana Vilacy. 2001. The morphosyntax of Mekens (Tupi). Ph.D. dissertation, University of Chicago.

Galucio, Ana Vilacy. 2002. Word order and constituent structure in Mekens. Revista da ABRALIN 1(2): 51-74. doi:10.5380/rabl.v1i2.52693

Galucio, Ana Vilacy. 2011a. Nominalization in the Mekens language. Amerindia 35: 237-60.

Galucio, Ana Vilacy. 2011b. Subordinate adverbial constructions in Mekens. In: Rik van Gijn, Katharina Haude, Pieter Muysken (eds.). Subordination in native South American languages: 25-44. Amsterdam: John Benjamins.

Galucio, Ana Vilacy. 2014. Estrutura argumental e alinhamento gramatical em Mekéns. In: Luciana Storto, Bruna Franchetto, Suzi Lima (orgs.). Sintaxe e semântica do verbo em línguas indígenas do Brasil: 167-96. Campinas: Mercado de Letras.

Galucio, Ana Vilacy, Antônia Fernanda de Souza Nogueira. 2012. Comparative study of the Tupari branch of the Tupi family: contributions to understanding its historical development and internal classification. In: Memorias del V Congreso de Idiomas Indígenas de Latinoamérica, 6-8 de octubre de 2011, Universidad de Texas en Austin. Austin: Center for Indigenous Languages of Latin America (CILLA). Retrieved from <https://ailla. utexas.org/sites/default/files/documents/Galucio_Nogueira_CILLA_V.pdf>, accessed on 02/07/2020.

Galucio, Ana Vilacy, Antônia Fernanda de Souza Nogueira. 2018. From object nominalization to object focus: the innovative A-alignment in the Tuparian languages (Tupian family). Journal of Historical Linguistics 8(1): 95127. doi:10.1075/jhl.16025.gal

Galucio, Ana Vilacy, Mercedes Guaratira Sakyrabiar, Manoel Ferreira Sakyrabiar, Rosalina Guaratira Sakyrabiar, Olimpio Ferreira Sakyrabiar. 2017. Sakurabiat. In: Kristine Stenzel, Bruna Franchetto (eds.). On this and other worlds: Voices from Amazonia: 331-51. Berlin: Language Science Press. doi:10.5281/zenodo.1008787 
Galucio, Ana Vilacy, Nilson Gabas Júnior. 2002. Evidências de agrupamento genético Karo-Puruborá, tronco Tupi. In: XVII Encontro Nacional da ANPOLL: boletim informativo $n^{\circ} 31$ : 163. Porto Alegre: Universidade Federal do Rio Grande do Sul.

Galucio, Ana Vilacy, Sérgio Meira, Joshua Birchall, Denny Moore, Nilson Gabas Júnior, Sebastian Drude, Luciana Storto, Gessiane Picanço, Carmen Reis Rodrigues. 2015. Genealogical relations and lexical distances within the Tupian linguistic family. Boletim do Museu Paraense Emílio Goeldi. Ciências Humanas 10(2): 229-74. doi:10.1590/1981-81222015000200004

Hanke, Wanda, Morris Swadesh, Arion Dall'Igna Rodrigues. 1958. Notas de Fonologia Mekens. In: Juan Comas (ed.). Miscellanea Paul Rivet octogenario dicata, vol. II: 187-217. Mexico City: Universidad Nacional Autónoma de México.

Landin, David. 2005. Dicionário e léxico Karitiana / português. $2^{\text {nd }}$ ed. Cuiabá: Sociedade Internacional de Lingüística.

Lacerda, María Conceição de. 2014. Bekã Pamakube (lugar de aprender). Aprendendo com os Zoró: análise da identidade indígena através da experiencia das escolas nas aldeias do povo indígena Zoró. Ph.D. dissertation, Universidad de Salamanca. doi:10.14201/gredos.124106

Lévi-Strauss, Claude. No date. Vocabulaires de trois langues: Kabišiana, Kepkiri-uat et de São Pedro. Ms. Paris.

Lévi-Strauss, Claude. 1950. Documents Rama-Rama. Journal de la Société des Américanistes 39: 73-84. doi:10.3406/jsa.1950.2381

Loukotka, Čestmír. 1963. Documents et vocabulaires inédits de langues et de dialectes sud-américains. Journal de la Société des américanistes 52: 7-60. doi:10.3406/jsa.1963.2001

Loukotka, Čestmír. Classification of South American Indian languages. Los Angeles: Latin American Center, University of California; Caracas: Sucre, 1968. (Reference Series, v. 7.)

Meira, Sérgio, Sebastian Drude. 2015. A summary reconstruction of Proto-Maweti-Guarani segmental phonology. Boletim do Museu Paraense Emílio Goeldi. Ciências Humanas 10(2): 275-96. doi:10.1590/1981-81222015000200005

Mello, Antônio Augusto Souza. 2000. Estudo histórico da família lingüística Tupi-Guarani: aspectos fonológicos e lexicais. Ph.D. dissertation, Universidade Federal de Santa Catarina.

Mondini, Juliana Nazatto. 2014. Yudja Utaha: a culinária juruna no Parque Indígena Xingu - uma contribuição ao dicionário bilíngue juruna-português. MA thesis, Universidade Estadual Paulista "Júlio de Mesquita Filho" (Araraquara campus).

Moore, Denny, Ana Vilacy Galucio. 1994. Reconstruction of Proto-Tupari consonants and vowels. In: Margaret Langdon, Leanne Hinton (eds.). Proceedings of the Meeting of the Society for the Study of the Indigenous Languages of the Americas, July 2-4, 1993, and the Hokan-Penutian Workshop, July 3, 1993, both held at the 1993 Linguistic Institute at Ohio State University in Columbus, Ohio: 119-37. Berkeley: Survey of California and other Indian Languages.

Nikulin, Andrey. Submitted. O Kabišiana de Lévi-Strauss é um codialeto do Sakurabiat (Mekéns).

Nikulin, Andrey, Fernando O. de Carvalho. 2019. Estudos diacrônicos de línguas indígenas brasileiras: um panorama. Macabéa - Revista Eletrônica do Netlli 8(2): 255-305.

Nikulin, Andrey, Mário André Coelho da Silva. 2020. As línguas Maxakalí e Krenák dentro do tronco Macro-Jê. Cadernos de Etnolingüística 8(1): 1-64.

Nikulin, Andrey, Serafima Muzykantova. In preparation. A phonological reconstruction of Proto-Ta-Arawakan.

Nogueira, Antônia Fernanda de Souza. 2011. Wayoro ẽmẽto: fonologia segmental e morfossintaxe verbal. MA thesis, Universidade de São Paulo. doi:10.11606/D.8.2011.tde-22102012-093617

Nogueira, Antônia Fernanda de Souza. 2015. Dissimilação em Wayoro (família Tuparí, tronco Tupí). In: Larissa Lima, Marília Ferreira, Eunice Braga, Jaqueline Reis, Zerben Aguiar (orgs.). Anais do IX Congresso Internacional da ABRALIN: 611-18. Belém: ABRALIN, PPGL/UFPA.

Nogueira, Antônia Fernanda de Souza. 2019. Predicação na língua Wayoro (Tupi): propriedades de finitude. Ph.D. dissertation, Universidade de São Paulo. doi:10.11606/T.8.2019.tde-14082019-101006

Nogueira, Antônia Fernanda Souza, Ana Vilacy Galucio, Nicole Soares-Pinto, Adam Roth Singerman. 2019. Termos de parentesco nas línguas Tuparí (família Tupí). Boletim do Museu Paraense Emílio Goeldi. Ciências Humanas 14(1): 33-64. doi:10.1590/1981.81222019000100004

Picanço, Gessiane Lobato. 2005. Mundurukú: phonetics, phonology, synchrony, diachrony. Ph.D. dissertation, University of British Columbia. doi:10.14288/1.0092991

Picanço, Gessiane Lobato. 2019. A fonologia diacrônica do Proto-Mundurukú (Tupí). Curitiba: Appris.

Ramirez, Henri, Valdir Vegini, Maria Cristina Victorino de França. 2017. O warázu do Guaporé (tupi-guarani): primeira descrição linguística. LIAMES 17(2): 411-506. doi:10.20396/liames.v17i0.8647468 
Reiter, Sabine. 2011. Ideophones in Awetí. Ph.D. dissertation, Christian-Albrechts-Universität zu Kiel.

Ribeiro, Maria de Jesus Pacheco. 2010. Dicionário Sateré-Mawé/português. MA thesis, Universidade Federal de Rondônia (Guajará-Mirim campus).

Rodrigues, Aryon Dall'Igna. 1958. Die Klassifikation des Tupi-Sprachstammes. In: Proceedings of the Thirty-Second International Congress of Americanists, Copenhagen 1956: 679-84. Copenhagen: Munksgaard.

Rodrigues, Aryon Dall'Igna. 1985. Evidence for Tupi-Carib Relationships. In: Harriet E. Manelis Klein, Louisa R. Stark (eds.). South American Indian languages: retrospect and prospect: 371-404. Austin: University of Texas Press.

Rodrigues, Aryon Dall'Igna. 2002. Correspondências lexicais e fonológicas entre Tupí-Guaraní e Tuparí. In: Ana Suelly Arruda Câmara Cabral, Aryon Dall'Igna Rodrigues (orgs.). Línguas indígenas brasileiras: Fonologia, gramática e história. Atas do I Encontro Internacional do Grupo de Trabalho sobre Línguas Indígenas da ANPOLL. Tomo I: 288-97. Belém: Editora da Universidade Federal do Pará.

Rodrigues, Aryon Dall'Igna. 2005. As vogais orais do Proto-Tupí. In: Aryon Dall'Igna Rodrigues, Ana Suelly Arruda Câmara Cabral (orgs.). Novos estudos sobre línguas indígenas: 35-46. Brasília: Editora UnB.

Rodrigues, Aryon Dall'Igna. 2007. As consoantes do Proto-Tupí. In: Ana Suelly Arruda Câmara Cabral, Aryon Dall'Igna Rodrigues (orgs.). Línguas e culturas Tupí, vol. I: 167-203. Campinas: Curt Nimuendajú; Brasília: LALLI/UnB.

Rodrigues, Aryon Dall'Igna, Ana Suelly Arruda Câmara Cabral. 2012. Tupían. In: Lyle Campbell, Veronica Grondona (eds.). The Indigenous languages of South America: a comprehensive guide: 495-574. Berlin/Boston: Mouton de Gruyter. (The World of Linguistics, 2). doi:10.1515/9783110258035.495

Rodrigues, Aryon Dall'Igna, Franz Caspar. 2017. Esboço da gramática da língua tuparí. Brasília: LALLI/UnB.

Sekelj, Tibor. 1948. Wordlist Aruá-Makurap-Zaboti-Arikapú-Tupari. Ms. Retrieved from http://etnolinguistica.wdfiles. com/local--files/sekelj\%3A1/Sekelj_Wordlist_Aru\%C3\%A1_Makurap_Zabot\%C3\%AD_Arikap\%C3\%B3_Tupar $\%$ C3\%AD.pdf, accessed on 28/08/2020.

Silva, Bazilio da, Nilzimara de Souza Silva, Odamir de Oliveira (orgs.). 2013. Paradakary urudnaa: dicionário Wapichana/português, português/Wapichana. Boa Vista: EDUFRR.

Singerman, Adam Roth. 2016. Nasal harmony and phonotactic well-formedness in Tupari. International Journal of American Linguistics 82(4): 453-85. doi:10.1086/688603

Singerman, Adam Roth. 2018. The morphosyntax of Tupari, a Tupian language of the Brazilian Amazon. Ph.D. dissertation, University of Chicago. doi:10.6082/ns2a-cv36

Snethlage, Emil Heinrich. 2015. Die Guaporé-Expedition (1933-1935): in Forschungstagebuch (aus dem Nachlass herausgegeben von Rotger M. Snethlage, Alhard-Mauritz Snethlage und Gleice Mere). Wien/Köln/Weimar: Böhlau Verlag. doi:10.7788/9783412218591

Valenzuela Bismarck, Pilar. 2011. Contribuciones para la reconstrucción del proto-cahuapana: comparacion léxica y gramatical de las lenguas jebero y chayahuita. In: Willem F. H. Adelaar, Pilar Valenzuela Bismarck, Roberto Zariquiey Biondi (eds.). Estudios en lenguas andinas y amazónicas. Homenaje a Rodolfo Cerrón-Palomino: 271-304. Lima: Fondo Editorial Pontificia Universidad Católica del Perú.

Voort, Hein van der. 2005. Kwaza in a comparative perspective. International Journal of American Linguistics 71(4): 365-412. doi:10.1086/501245

Voort, Hein van der. 2007. Proto-Jabutí: um primeiro passo na reconstrução da língua ancestral dos Arikapú e Djeoromitxí. Boletim do Museu Paraense Emílio Goeldi. Ciências Humanas 2(2): 133-68. doi:10.1590/S198181222007000200007

Wetzels, W. Leo, Andrew Nevins. 2018. Prenasalized and postoralized consonants: The diverse functions of enhancement. Language 94(4): 834-66. doi:10.1353/lan.2018.0055

Xerez, Sebastião Moacyr. 1946. Pequeno vocabulário dos dialetos Macurape, Mondé e Caritiana. Manaus.

А.Никулин, Р.Андради. Развитие и падение аппроксимантов в языках тупарийской группы

В статье рассматривается развитие серии аппроксимантов в языках тупарийской группы (тупийская семья), изначально распространённых между средним течением реки Гуапоре́/Ите́нес и верховьями Маша́ду/Жи-Парана́ (юг штата Рондония, Бразилия). Показано, что помимо исходной серии пратупарийских аппроксимантов (в нашей ре- 
конструкции, ${ }^{*} \beta,{ }^{*} j$ и $\left.{ }^{*} w\right)$ в некоторых языках-потомках развились аппроксиманты и из других источников - из гласных ненижнего подъёма $\left({ }^{*} o{ }^{*} i\right)$, посторализованных носовых $\left({ }^{*} m b /{ }^{*} n d /{ }^{*} \eta g\right.$, через ступень $\left.{ }^{*} b{ }^{*} d{ }^{*} g\right)$ и глайдов, заполняющих зияние. Детально обсуждается эволюция этих звуков; в частности, показывается, что во всех тупарийских языках хотя бы некоторые бывшие аппроксиманты подверглись фортиции. Особое внимание уделяется внутренней классификации тупарийской группы.

Ключевые слова: тупарийская группа; тупийская семья; аппроксиманты; фортиция; сравнительно-исторический метод. 